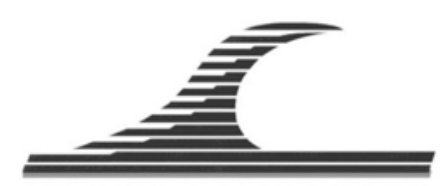

REVUE PARALIA

Mots-clés : Intertidal hydro-sedimentary processes, Mont-Saint-Michel bay, Mega-tidal regime, Sedimentary dynamics, Modifications, Recent evolution.

(C) Editions Paralia CFL

\title{
Intertidal sedimentary dynamics in Mont-Saint-Michel bay, a study of its natural evolution and man-made modifications
}

\author{
Chantal BONNOT-COURTOIS ${ }^{1}$ \\ a tribute to Alain L'HOMER †
}

\author{
1. CNRS, UMR 8586 PRODIG, Laboratoire de Géomorphologie et \\ Environnement Littoral EPHE, 15 boulevard de la mer, 35800 Dinard.
}

\section{Summary:}

Due to its exceptional tidal range and the immensity of its intertidal zones, Mont-SaintMichel is a favored model for research on coastal hydro-sedimentary processes, presentday sedimentary dynamics and the reconstruction of coastal paleo-environments. The purpose of this article is to analyze the erosion/sedimentation processes which govern the sedimentary dynamics and the recent evolution of the characteristic sedimentary environments of the bay. The western bay head is made up of tidal sand and silt deposits, where the extent of the surface sediment reworking is less than $10 \mathrm{~cm}$ and linked to the nature of the substrate and the wind direction. Added to these tidal dynamics are the dynamics of the swell, which set coarse bioclastic sands in motion as the waves wash away the shore. These sands migrate on the tidal flat at rates of several dozen $\mathrm{m}$ /year and accumulate on the upper tidal flat, forming a relatively stable noncontinuous coastal barrier of large shell banks. The eastern part of the bay is an estuarine zone, where the morpho-dynamics of the sandy tidal flat are constrained by shifting channels. Studies of the interaction between vegetation and sedimentation around Mont-Saint-Michel show sedimentary accretion rates varying from 0.2 to 10 $\mathrm{cm} /$ year, depending on the morpho-dynamic context of the salt marsh front. The volume of sediment deposited by the tide leads to cyclical deposition of calcareous muds followed by the steady advance of salt marshes at a rate of about $17 \mathrm{ha} /$ year between $L a$ Chapelle Sainte-Anne and the Roche Torin point. The bay has filled for thousands of years to the rhythm of sea level oscillations, leading to the gradual infilling of the Dol marsh and the advance of the shoreline. In addition to this natural evolution, human activities have developed in the bay, both on the western tidal flat (fixed fisheries and shellfish farming) and on the eastern estuarine side (polder formation, construction of dikes and a dam) and have altered the landscapes, the historical evolution of which was reconstructed from old documents.

Paper originally presented during the colloquium "XII èmes Journées Nationales Génie Côtier Génie Civil", Cherbourg (France), 12-14 June 2012. Received 15 June 2016, accepted 15 September 2016, available online 3 May 2020.

Translated version.

Pour citer cet article :

BONNOT-COURTOIS C. (2020). Intertidal sedimentary dynamics in Mont-Saint-Michel bay, a study of its natural evolution and man-made modifications. Revue Paralia, Vol. 13, pp n02.1-n02.34. 


\section{Foreword}

This article is a synthesis of the hydro-sedimentary studies conducted in Mont-SaintMichel bay from the year 2000 onward at the EPHE Geomorphology and Coastal Environment Laboratory of the PRODIG Combined Research Unit (UMR) 8586 at the French National Scientific Research Centre (CNRS). The studies were funded under several research programs, in particular the "Environmental Studies" section of the Project for Restoring Mont-Saint-Michel to a marine setting (Mont-Saint-Michel Mission of the Manche Department Infrastructure Directorate and the Joint Association for Restoring the Mont-Saint-Michel to a marine setting) and the "Trophic Capacity of Mont-Saint-Michel bay" project of the National Coastal Environment Project (PNEC of the French National Scientific Research Centre- CNRS).

This work could never have come to fruition without the cooperation of numerous colleagues to whom I would like to extend my thanks: A. Baltzer, B. Tessier (CNRS / Univ. Caen), M. Le Vot and H. Gloria (EPHE, Dinard), J.E. Levasseur (Univ. Rennes 1), B. Caline, (TOTAL, Pau), R. Desguée (Mont Saint-Michel Bay Joint Association), J.Y Cocaign (Vains Ecomuseum, CG50), C. Billard (DRAC-SRA, Basse Normandie), P. Le Mao, C. Rollet (Ifremer, Dinard), C. Retière, (MNHN, Dinard) C. Augris, Ph. Bassoullet, J.P. Mazé, P. Le Hir, J. Populus, (Ifremer, Brest), along with all the students and technicians who took part in this research.

Finally, I would like to express my special thanks to Alain L'HOMER, who passed away in 2011 and whom I would like to sincerely thank for sharing his encyclopedic knowledge of the sedimentary environments of the bay and its marshes, from which he was able to reconstruct the evolution of the landscapes presented in this article.

\section{Introduction}

Sheltering numerous highly important natural habitats, Mont-Saint-Michel bay has been chosen to become part of the European Natura 2000 network of sites, and Mont-SaintMichel itself is a World Heritage site, which entails a precise analysis of the natural evolution of these highly coveted environments, subject to a variety of human activities. Two recent programs have provided an opportunity to study the present-day intertidal sedimentary dynamics in finer detail.

As part of the hydro-sedimentary theme of the "Trophic Capacity of Mont-Saint-Michel bay" project of the National Coastal Environment Program (PNEC), a new morphosedimentary map of the bay has been produced and coupled with a LIDAR survey of the entire bay, highlighting the levels of submergence of the tidal flat and correlating them with the present-day sedimentary dynamics. In addition, erosion/sedimentation processes have been measured in situ in order to monitor the amplitude of reworking and the movement of the surface silt layers. Furthermore, a chronologically-arranged set of aerial photographs dating from 1952 was compared and geo-referenced against the 
Ortho-littoral 2000 survey. This allowed a quantitative assessment of the dynamics of the shell banks which form the coastal area of the western upper tidal flat.

As part of the project for restoring Mont-Saint-Michel to a marine setting, the environmental studies of salt marsh dynamics led to analysis of the interaction between vegetation and sedimentation in the salt marshes around Mont-Saint-Michel. Measurement of sedimentary accretion and deposition of suspended material at the salt marsh front demonstrates the influence of the morpho-dynamic conditions of the upper mudflat on the evolution of the salt marshes. The same chronological set of aerial photographs that was used for the shell banks also served to precisely quantify the advance or retreat of the salt marshes around Mont-Saint-Michel.

Finally, the evolution of the landscapes of the bay was reconstructed from old documents. This made it possible to trace the impact of successive modifications made to the entire tidal flat over the centuries.

\section{General presentation. Physical background}

Mont-Saint-Michel bay has been the object of innumerable scientific works in domains including sedimentology, biology and archaeology. A non-comprehensive list of the main reference and synthesis works is provided in the bibliography.

Between the Pointe du Grouin to the west and the Pointe de Champeaux to the east, 250 $\mathrm{km}^{2}$ of the Mont-Saint-Michel bay tidal flat can be divided into two major morphosedimentary sections. The western domain from Cancale to Cherrueix is a sheltered bay head across $5 \mathrm{~km}$ of homogeneous silts cut through by the outflows of drainage channels from the Dol marsh. The western section is a huge estuarine domain at the mouth of three slow-flowing coastal rivers: the Sée, the Sélune and the Couesnon. This eastern tidal flat, $10 \mathrm{~km}$ wide and criss-crossed by a dense network of tidal channels, is subject to an intense hydrodynamic regime which re-mobilizes the sand beds. The boundary between the Western Bay and the Eastern estuarine zone is marked by a reef of Annelids (Sabellaria alveolata) which has developed on the lower tidal flat, forming the hermella bank. (LARSONNEUR \& coll., 1989; L'HOMER et al., 1999; BONNOTCOURTOIS et al., 2002).

\subsection{Hydrodynamic context}

With their exceptionally high range in Mont-Saint-Michel bay (the tidal range of spring tides is $14 \mathrm{~m}$ ), the tides play a crucial role in the distribution of sediments in the shallow depths and on the tidal flat. Two tidal current regimes coexist in the bay (figure 1):

a) the currents alternate off the Pointe $d u$ Grouin and to the north-east on the median line of the bay; the flood tide flowing toward the south-east is more intense than the ebb tide flowing toward the north-west. At the entrance to the bay, the currents can reach over $1 \mathrm{~m} / \mathrm{s}$, before slowing down to about $0.6 \mathrm{~m} / \mathrm{s}$ on the tidal flat, except in the estuarine channels where they can exceed $2 \mathrm{~m} / \mathrm{s}$. 
b) to the south-west, the currents rotate. The flood tide still predominates over the ebb tide, but at a highly reduced speed $(0.3 \mathrm{~m} / \mathrm{s})$ in the Cancale Bay.

The prevailing winds are westerly to north-westerly and the swell usually comes from a west-north-westerly direction (figure 2).

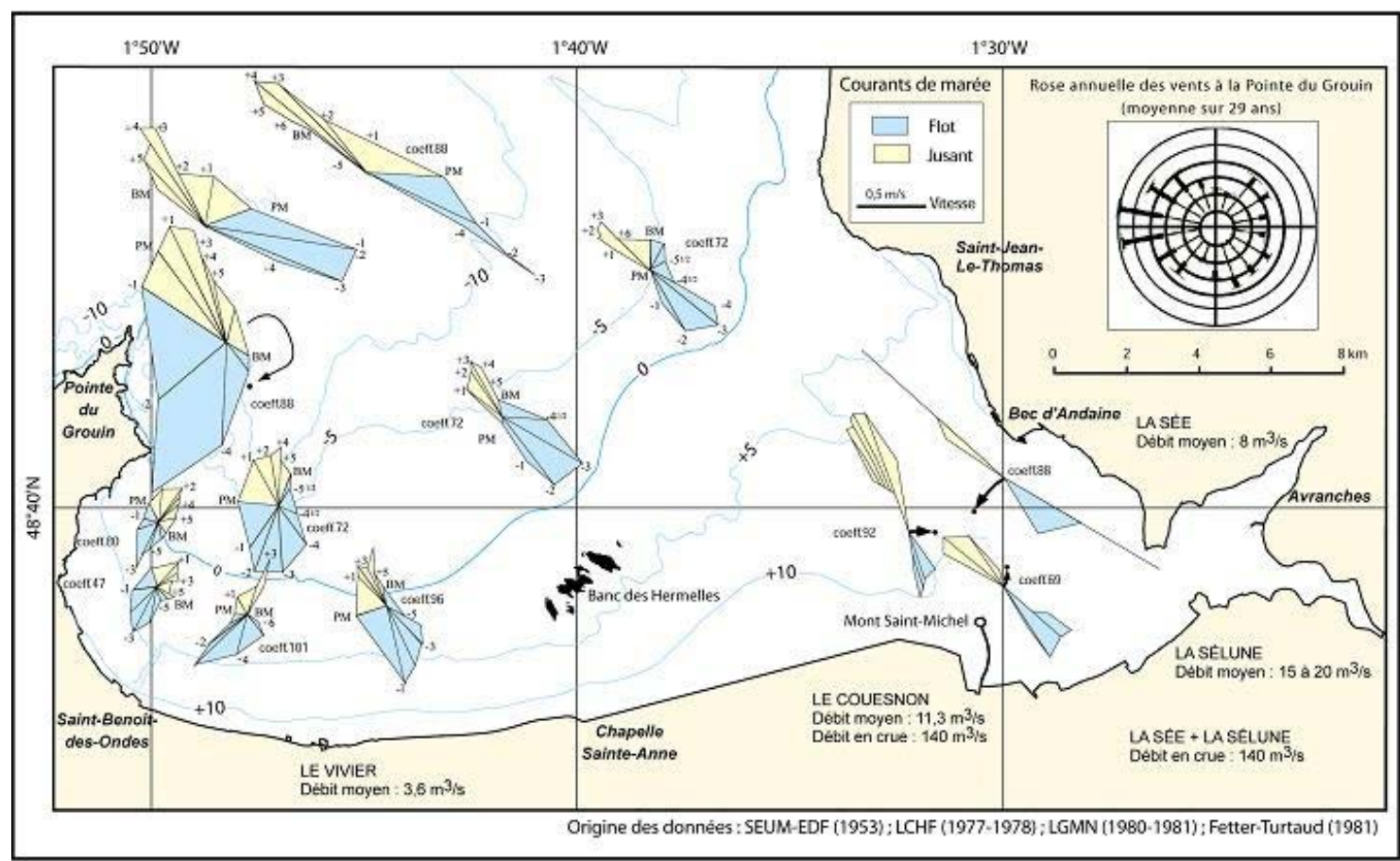

Figure 1. Rose diagrams of the tidal currents and winds in Mont-Saint-Michel bay.

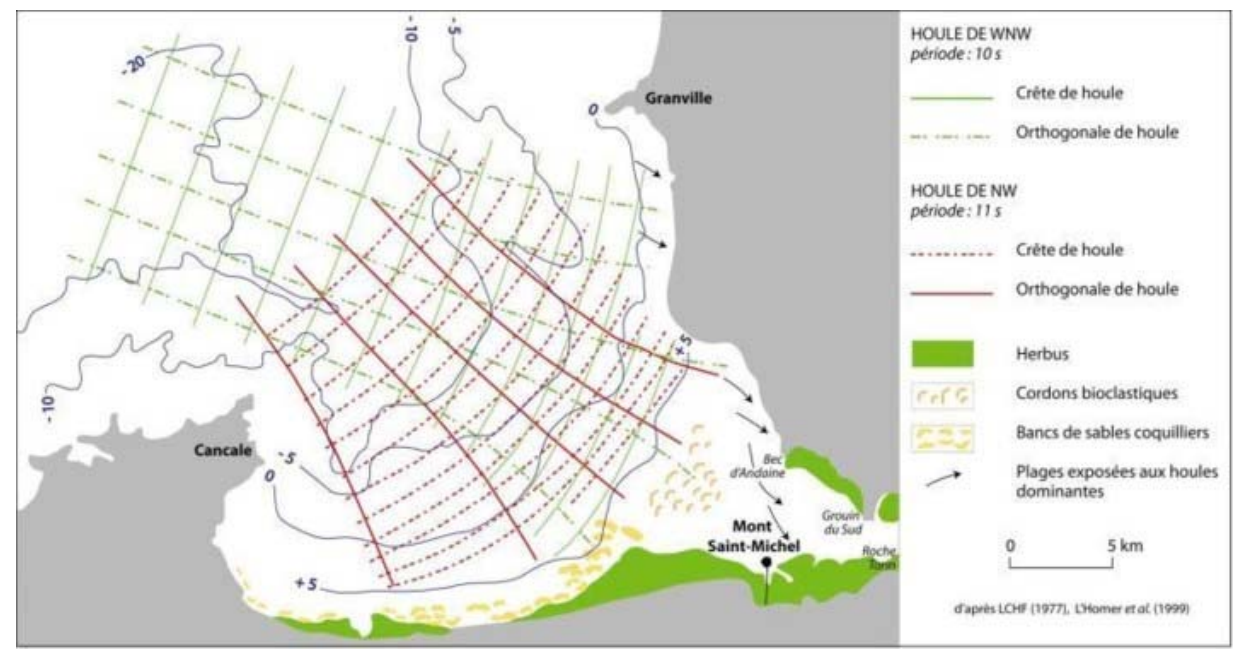

Figure 2. Plan view of the swell in the western sector of Mont-Saint-Michel bay.

At the entrance to the bay, the swell is refracted around the Pointe du Grouin and thus Cancale Bay is completely protected from wave action. Moving along the median line 
of the bay, the swell subsides almost completely due to friction on the level tidal flat, which is particularly broad in the estuarine zone. The effect of the swell is particularly evident on the Normandy coast between Saint-Jean-le-Thomas and the Bec d'Andaine (TESSIER et al., 2006), and to a lesser extent on the western tidal flat at the centre of the bay, where the refracted swell in the northern sector causes the accumulation of shell banks on the upper tidal flat between Saint-Benoit-des-Ondes and La Chapelle Sainte-Anne (MIGNIOT, 1998; L'HOMER et al., 1999).

\subsection{Morpho-sedimentary map (figure 3)}

As part of the hydro-sedimentary theme of the "Trophic capacity of Mont-Saint-Michel bay" project of the National Coastal Environment Program (PNEC, 2007), the status of the sedimentary cover of the bay was updated on the basis of an analysis of 400 sedimentary and biological samples taken at regular intervals (1 sampling point per $\mathrm{km}^{2}$ ) in the intertidal and sublittoral zone. The intertidal map was drawn up by correlating the results of the laser grain-size analysis, characterizing the nature of the sedimentary facies, and by interpreting the raw IGN 2002 Ortho-littoral photographs which served as a support for determining the facies boundaries (BONNOTCOURTOIS et al. 2007).

The marine domain, at the bay entrance, comprises gravel and pebble banks on a rock substratum with widespread outcrops to the north-east of the Pointe du Grouin. These very coarse sediments give way to sandy gravels which form banks close to the headlands. To the north-west of the bay, they are mixed with an abundant stock of shells, particularly the American slipper limpet, an invasive species that covers extensive areas of the sublittoral beds up to the silty sections of the Cancale oyster beds. Gullies made of shelly gravel and coarse sand, forming megaripples in places, cut across the sandy prism between the hermella bank and the Pointe de Champeaux. At the centre of the bay, the bank situated to the north of the Sainte-Anne hermella reef coincides with the old bed of the Couesnon. To the north-east, the gully anchored on the Pointe de Champeaux includes better-graded coarse sand, indicating active sedimentary dynamics.

Distribution of the sublittoral and intertidal sediments in Mont-Saint-Michel bay reflects the predominant action of tidal currents, which gradually lose speed from the open sea toward the coastline. Two major sedimentary gradients appear in relation to this hydrodynamic attenuation:

- from the open sea toward the coast, the coarse sand and gravel layers aligned in a north-westerly - south-easterly direction in parallel to the bay, gradually give way to medium and fine-grained sand and subsequently to silty facies on the highest parts of the tidal flat.

- from east to west, the fine sands of the estuarine zone deposited by the action of alternating tidal currents give way to sandy-silty facies in the central part of the bay. 
Even finer silty facies are found in Cancale Bay, subject to rotating currents and totally protected from the north-westerly swell refracted by the Pointe du Grouin.

Nature des sédiments superficiels

Roche toujurs immergée (a)
Cailloutis et blocs
Graviers et calloutis
Graviers et sables grossiers
Sables grossiers, graviers, calloux
Sables moyens et grossiers à graviers
Sables grossiers
Sables moyens et grossiers bioclastques
Sables moyens
Sabies moyens des chenaux
Sables fins

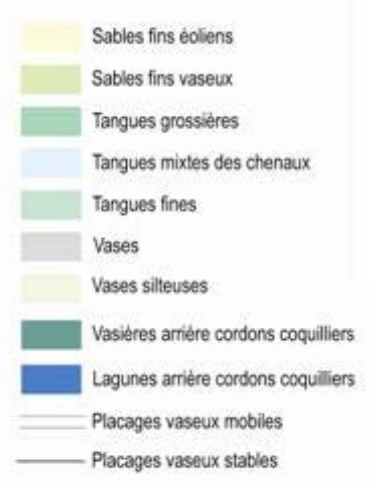

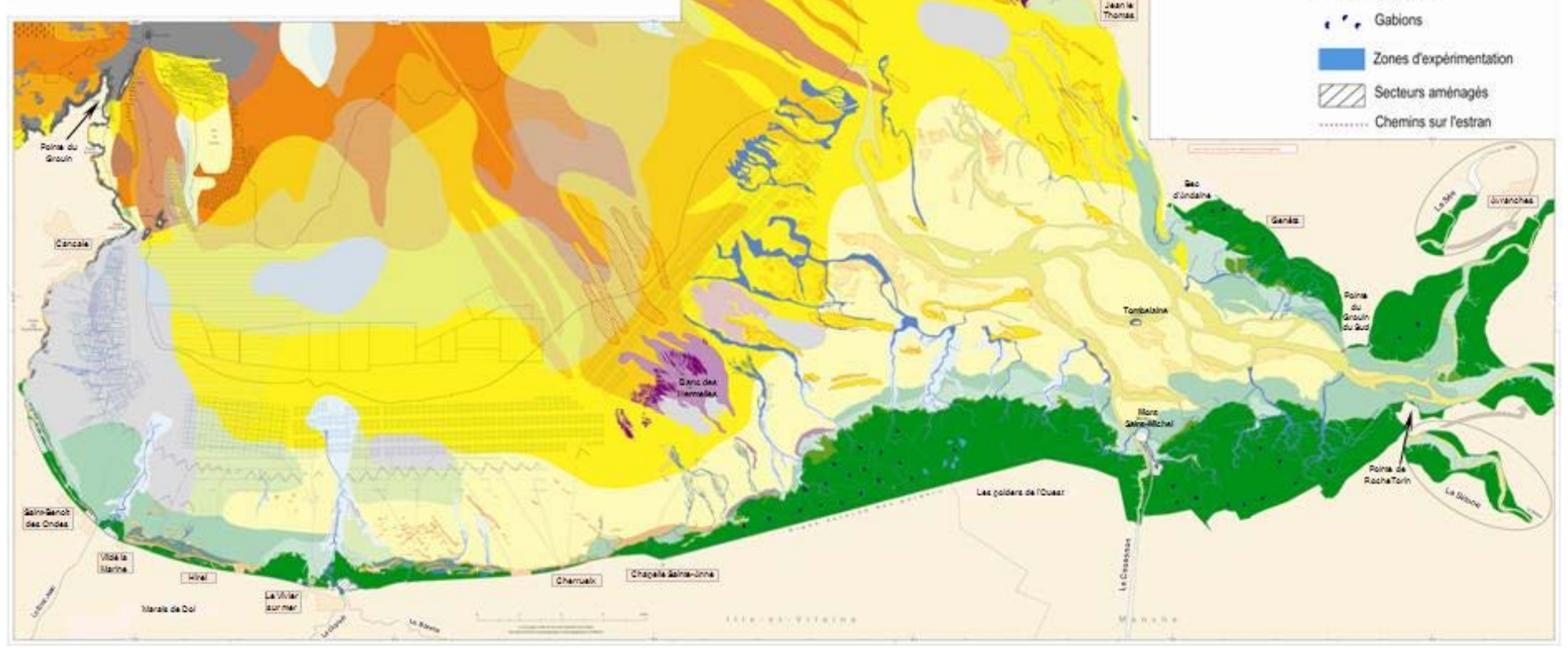

\section{Morphologie \& figures sédimentaires}

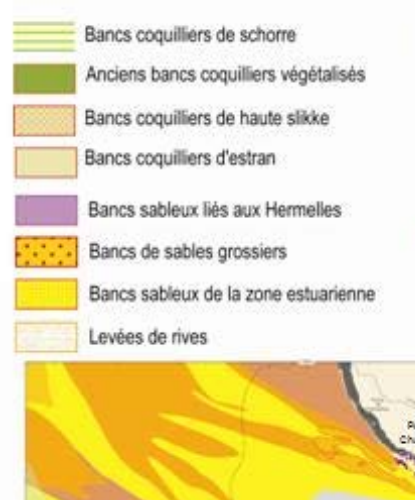

C. Chenaux d'estran

(6). Rubans sableux

E- Mégarides (longueur d'onde $<5 \mathrm{~m}$ )

_- Mégarides (longueur ofonde $>5 \mathrm{~m}$ )

Crette de dune hydraulique

Crete de banc

Rides de bas estran

$-\infty$ - Isobathe en $m$ (SHOM)

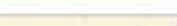

Biocénoses remarquables

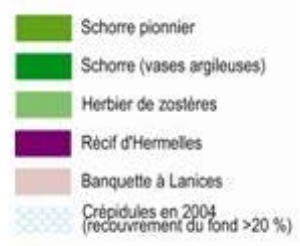

Aménagements

$\square$ ostreiculture Ostrticulture
en zone decouvrante

Ixistil Masiculture

Plcheries

Figure 3. Distribution of surface sediments in Mont-Saint-Michel bay (after BONNOTCOURTOIS et al. 2009).

The sedimentary facies in the west range from a level tidal flat made up of pure silt at Cancale, to a sandy-silty environment opposite Vildé-Hirel and subsequently to a tidal flat formed of fine and medium-grained sand off Cherrueix to the east of the Vivier channel. The lower tidal flat of this western bay head is marked by the major development of shellfish farming installations: oyster farming in Cancale Bay and mussel farming between Vildé-la-Marine and beyond Cherrueix, up to the area off the hermella reef and the mouth of the estuarine zone. There are also numerous old fisheries in an almost continuous line on the middle tidal flats between Saint-Benoît-des-Ondes and Cherrueix. 


\subsection{Topography and submergence of the tidal flat. LIDAR data}

As part of the National Coastal Environment Program (PNEC), a digital terrain model of the entire bay was created on the basis of a bathymetric survey of the shallow sublittoral depths and a LIDAR topographic survey of the tidal flat carried out in 2002 (figure 4). LIDAR coverage, with a resolution of $2 \mathrm{~m}$ at ground level and vertical precision better than $15 \mathrm{~cm}$, offers extremely interesting possibilities to map the topography of the intertidal zone and the morphology of the sedimentary units in detail.

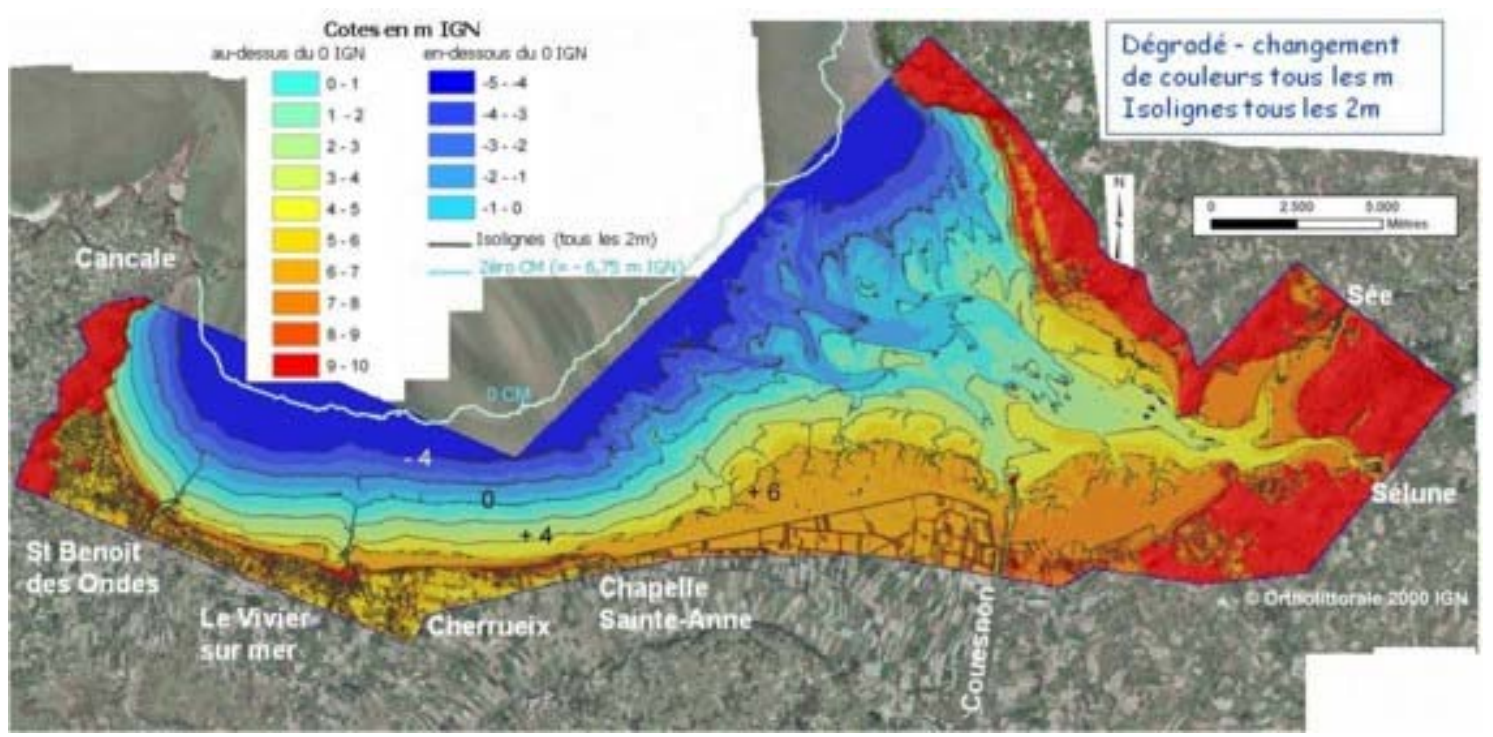

Figure 4. Digital Terrain Model (DTM) from the 2002 LIDAR survey.

The topography of the western part of the tidal flat between Cancale and La Chapelle Sainte-Anne is even and gently inclined, only interrupted by the outflows of two Dol marsh drainage channels at Saint-Benoît-des-Ondes and Le Vivier-sur-Mer. The western tidal flat is about $5 \mathrm{~km}$ wide and the gradients vary from $0.55 \%$ at Vildé Hirel to $0.38 \%$ at Cherrueix, shallowing to $0.31 \%$ at La Chapelle Sainte-Anne. The gradients are even shallower in the estuarine zone - of the order of $0.15 \%$ - where the tidal flat is over 10 $\mathrm{km}$ wide. The mean tide level ( 0 IGN) is $6.74 \mathrm{~m}$ above chart datum (0 CM) and the $6 \mathrm{~m}$ IGN elevation level corresponds to the limit of the continuous vegetation cover on the eastern upper tidal flat.

Correlating this fine topography, covering the entire intertidal zone, with the tide levels for all coefficients classified in increments of 10 enables us to identify the submergence levels of the tidal flats. The High Water and Low Water levels have been calculated on the basis of a 50-year average (for the period 1950-2000) in order to smooth out the 
effects of variations from year to year (4-year cycles and Saros tides at 18-year intervals) (figure 5) (BONNOT-COURTOIS et al. 2009; WEILL, 2010).

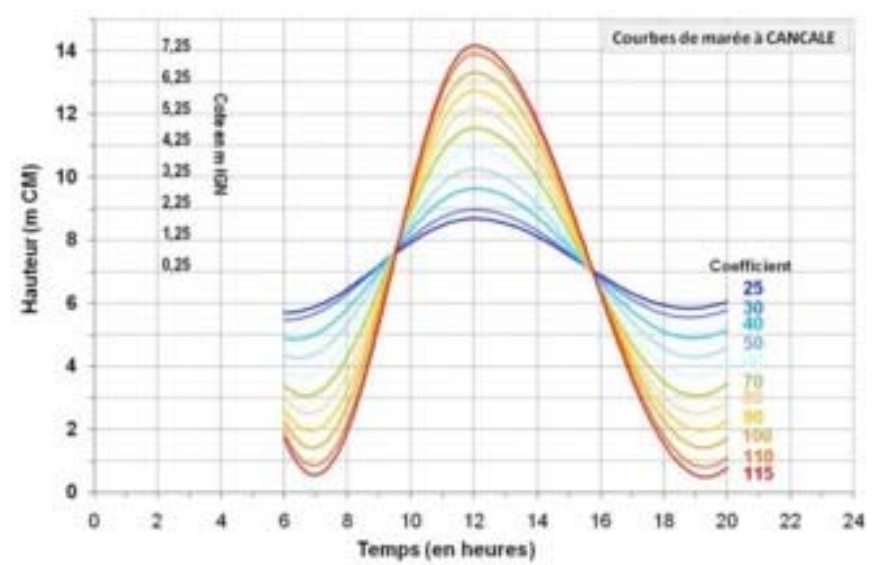

Figure 5. Mean tide curves by coefficient at Cancale.

The theoretical average High-Water and Low-Water levels thus obtained are entered on the intertidal topographic map and allow the sweep of the tide on the tidal flat to be identified for all types of neap or spring tides (figure 6). The area uncovered during spring tides is about twice as extensive as during neap tides. It is also much larger in the estuarine zone (about $10 \mathrm{~km}$ during spring tides) than in the Cancale Bay (5 km during spring tides).

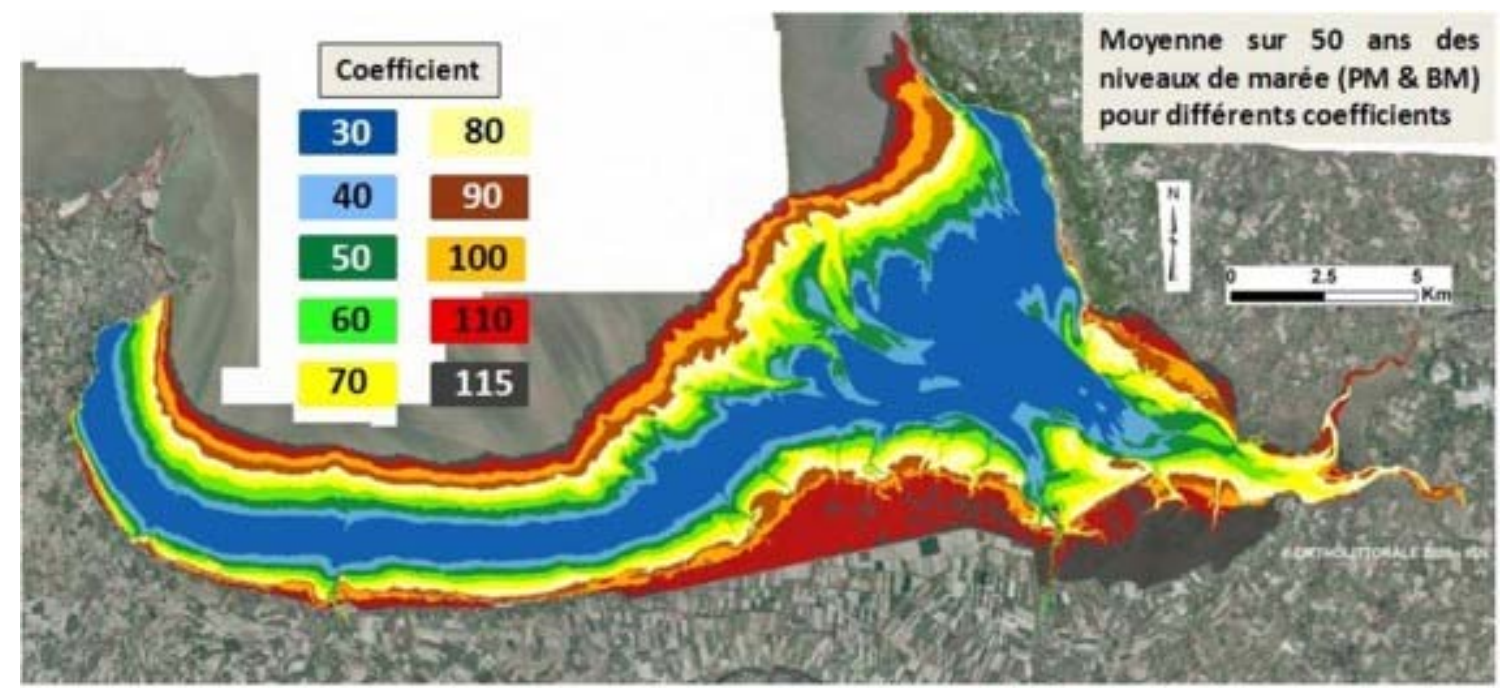

Figure 6. Tidal sweep of the intertidal zone for the different coefficients classified in increments of 10. Mean High-Water and Low-Water levels defined over a 50-year period (1950 to 2000). 


\section{Sedimentary processes and dynamics on the western upper tidal flat}

\subsection{Erosion - sedimentation on the western tidal flat}

The objective of the hydro-sedimentary theme of the PNEC was to classify the dissolved and particulate matter transported and to analyze the periodicity and intensity of erosion-sedimentation processes occurring on these enormous tidal ledges where shellfish farming installations have been established. Variations in sediment level have been monitored on three timescales along three transverse radii several kilometres long, representative of the different sedimentary environments: silty at Cancale, sandy-silty at Vildé-Hirel and sandy at Cherrueix. Changes in the surface sedimentary cover and the phases of erosion and deposition identified depend on location on the tidal flats and on the meteorological and tidal conditions (BONNOT-COURTOIS et al., 2006, 2007).

Reworking only affects less than $5 \mathrm{~cm}$ and varies from West to East: considerable at Cancale and Vildé-Hirel and much lower at Cherrueix. At particular times of the year, especially in the winter, the entire tidal flat undergoes phases of erosion of several centimetres, quickly followed by phases of sedimentation of the same amplitude. A spatial balance appears to exist between the two western radii: an erosion phase of the surface silts at Hirel coincides with a sedimentation phase at Cancale. Therefore, the erosive action of the north-westerly winds over the entire Cancale tidal flat may be related to the deposition of fine sediments by the same winds in the area upstream of the Vildé-Hirel fisheries. Similarly, south-easterly winds erode the middle tidal flat at VildéHirel while building up the mud flat at Cancale.

\subsection{Dynamics of the shell banks}

The western upper tidal flat of Mont-Saint-Michel bay between Saint-Benoît-des-Ondes and La Chapelle Sainte-Anne are characterized by large shell banks aligned parallel to the coastline. These bioclastic accumulations are related to wave action and present different types of morphology according to their morpho-sedimentary characteristics: grain size, bioclastic content, amplitude, position on the tidal flat, etc. The sandbanks on the middle section of the tidal flat $(30 \mathrm{~cm})$ are thin, but very extensive. On the upper tidal flat, the shell-rich upper mudflat banks are very thick $(2 \mathrm{~m})$ and asymmetrical, with a gentle gradient toward the sea and a steep gradient toward the shore, with their extremities bent toward the coastline. Located at the edge of the salt marsh, they isolate a lagoon-like depression behind them, where fine silts are deposited, particularly in the areas of Vildé-Hirel and Cherrueix (figure 7). The salt marsh banks of variable thickness and limited lateral extent are mainly formed of intact shells and are swallowed up by the salt marsh, where they have gradually become overgrown by dune vegetation. 
At Vildé-Hirel, the banks on the tidal flat are discrete on the mixed sandy silt flat and the long upper mudflat banks form an almost continuous coastal barrier. At Cherrueix, a multitude of small tidal-flat banks lie on different levels on a tidal flat of fine sand and the upper-mudflat shell banks are arranged in several non-continuous lines. At La Chapelle Sainte-Anne, tidal-flat banks are uncommon on the fine and medium-grained sand flat and a few extensive upper-mudflat banks can be seen in the western part of the area. Toward the East, they give way to the large litho-bioclastic banks associated with the hermella reefs.

The LIDAR survey shows that these banks are high (7.5 m IGN) and that they are only exceptionally covered during maximum high water springs (figure 7). There are longitudinal variations in the submergence of the upper-mudflat banks, the base of which is reached by high waters of coefficient 100 in the West and only 90 in the East. At La Chapelle Sainte-Anne, submergence is almost complete at coefficients of 100, while some banks forming the coastal barrier at Cherrueix and at Vildé-Hirel remain dry even when the coefficient is 115 (theoretical water levels in the absence of depression and turbulent conditions). This coastal barrier of bioclastic banks can only be reworked when periods of intense wave action combine with spring tides.

Analysis of a chronological set of aerial photographs (14 assignments every five years on average) between 1947 and 2006 (figure 8a) shows that the rate of migration of the banks from the lower tidal flats to the coastline varies from several dozen metres per year for the banks on the middle tidal flat to a few metres per year for those located at the edge of the salt marsh (figure 8b).

At the same distance from the shore, the migration rates of the banks appear to diminish from West to East (figure 9) according to the differences in gradient between the tidal flats at Vildé-Hirel, Cherrueix and La Chapelle Sainte-Anne. As the width of the intertidal zone increases toward the estuarine zone, the gradients of the tidal flat diminish from West to East. When examined in relation to the elevation of the tidal flats, the migration rate variation curves become consistent between these three sectors. On the lower tidal flat, the banks migrate at rates exceeding $100 \mathrm{~m} /$ year. The rates

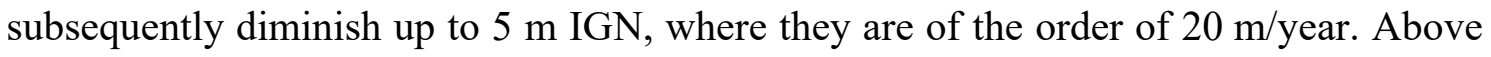
$6 \mathrm{~m} \mathrm{IGN}$, the movement of the banks slows down to a few metres per year, stabilizing at the coastal barrier on the edge of the salt marsh.

The nature of the sediment along the tidal flat, the gradient of the tidal flats and the submergence levels are the factors which determine the morphogenesis and evolution of the bioclastic accumulations to the west of the bay. The fact that, according to the chronological set of aerial photos examined, the bank migration rate has not increased suggests that the submergence factor smoothes out drastic changes related to periods of intense wave action. 


\section{Chapelle Sainte-Anne}
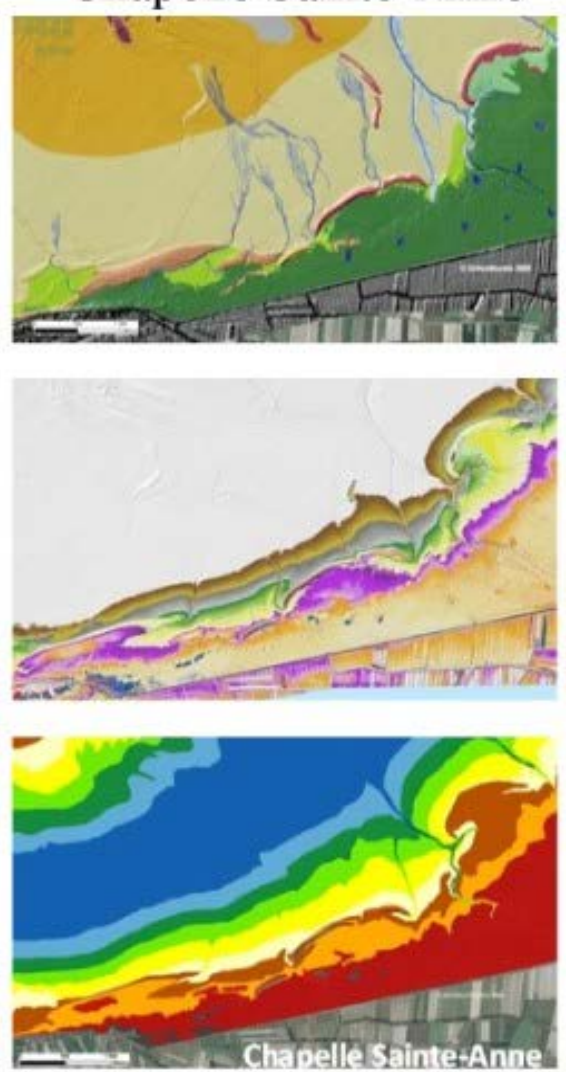

Vildé-Hirel

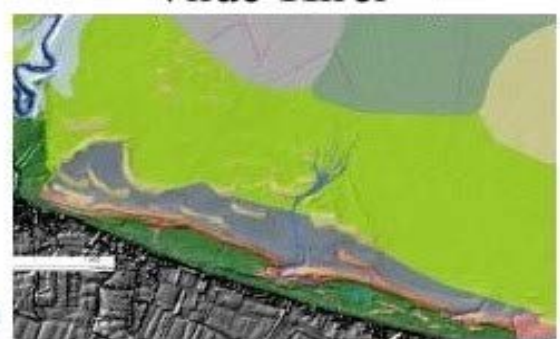

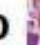
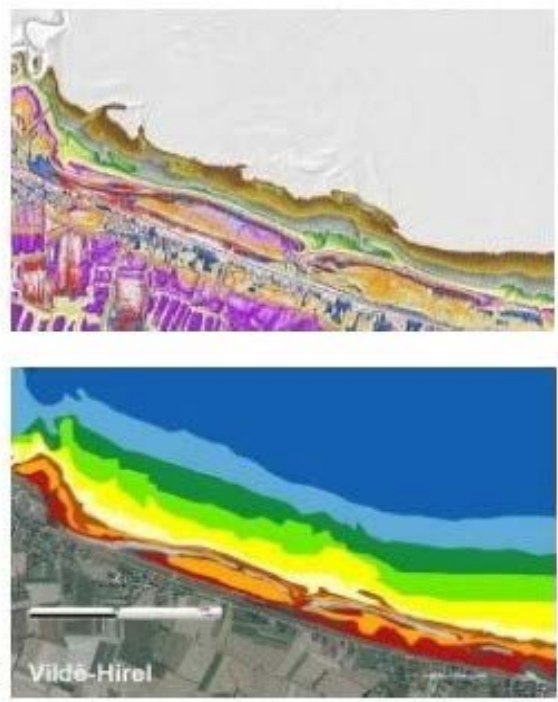

Cherrueix

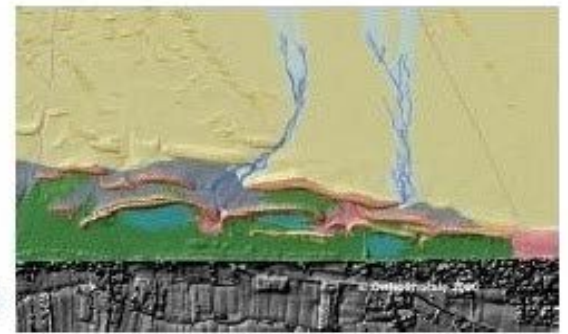

b

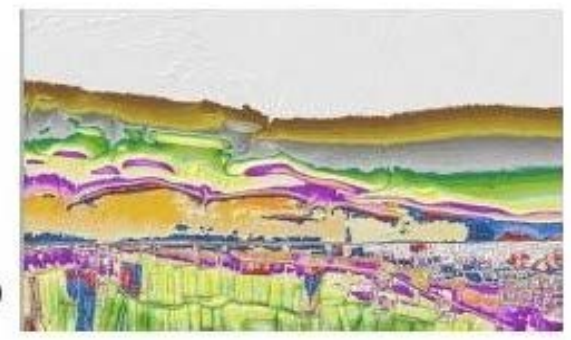

C

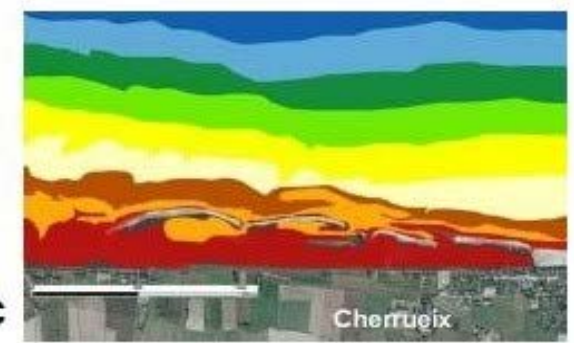

\begin{tabular}{|lll|}
\hline Cotes IGN & $\begin{array}{l}\text { Coefficient de } \\
\text { maree }\end{array}$ & $\begin{array}{l}\text { \% de dipassement } \\
\text { ducoeff. sur l'ennée }\end{array}$ \\
\hline$<4 \mathrm{~m}$ & & $65 \%$ \\
$4-4,5 \mathrm{~m}$ & $60[10,75 \mathrm{~m} \mathrm{CM})$ & $50 \%$ \\
$4,5-5 \mathrm{~m}$ & 70 & $42 \%$ \\
$5-5,5 \mathrm{~m}$ & 75 & $36 \%$ \\
$5,5-6 \mathrm{~m}$ & 80 & $20 \%$ \\
$6-6,5 \mathrm{~m}$ & 90 & $8 \%$ \\
$6,5-7 \mathrm{~m}$ & 100 & $3 \%$ \\
$7-7,5 \mathrm{~m}$ & 110 & $1 \%$ \\
$7,5-8 \mathrm{~m}$ & $115(14,25 \mathrm{~m} \mathrm{CM})$ & \\
\hline$>8 \mathrm{~m}$ & & \\
\hline
\end{tabular}

Niveau moyen des Pleines Mers (marées de morte-eau à vive-eau)

\begin{tabular}{|l|l|}
\hline Coeff. 30 & Coeff. 80 \\
\hline Coeff. 40 & Coeff. 90 \\
\hline Coeff. 50 & Coeff. 100 \\
\hline Coeff. 60 & Coeff. 110 \\
\hline Coeff. 70 & Coeff. 115 \\
\hline
\end{tabular}

Figure 7. (a) Morpho-sedimentary map, (b) LIDAR topographic survey and (c) submergence levels of the shell banks of the upper tidal flat at Vildé-Hirel and Cherrueix. 

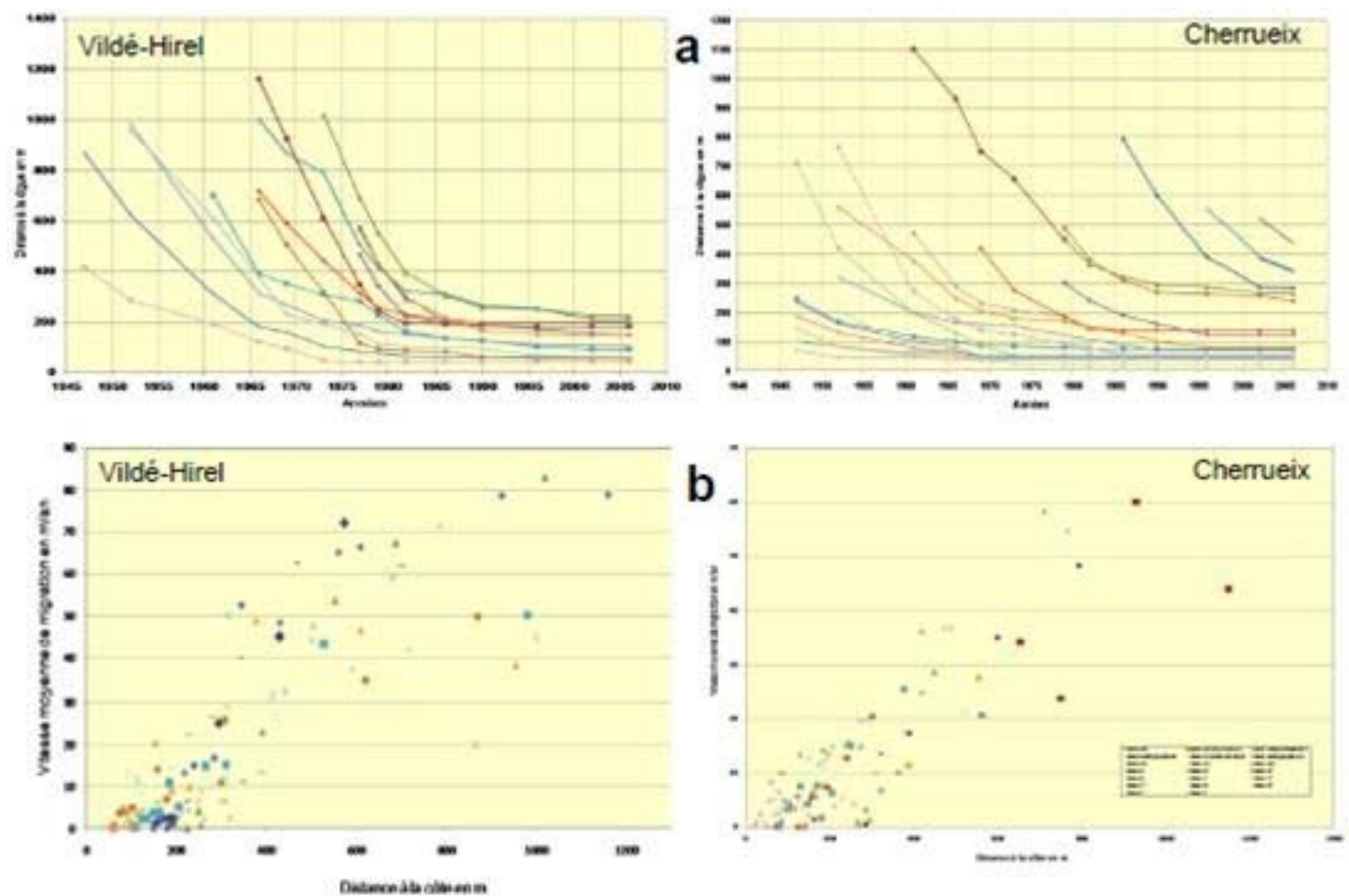

Figure 8. a: Migration of the banks toward the coastline between 1947 and 2006 $\boldsymbol{b}$ : Migration rate of the banks in relation to their position on the tidal flats.

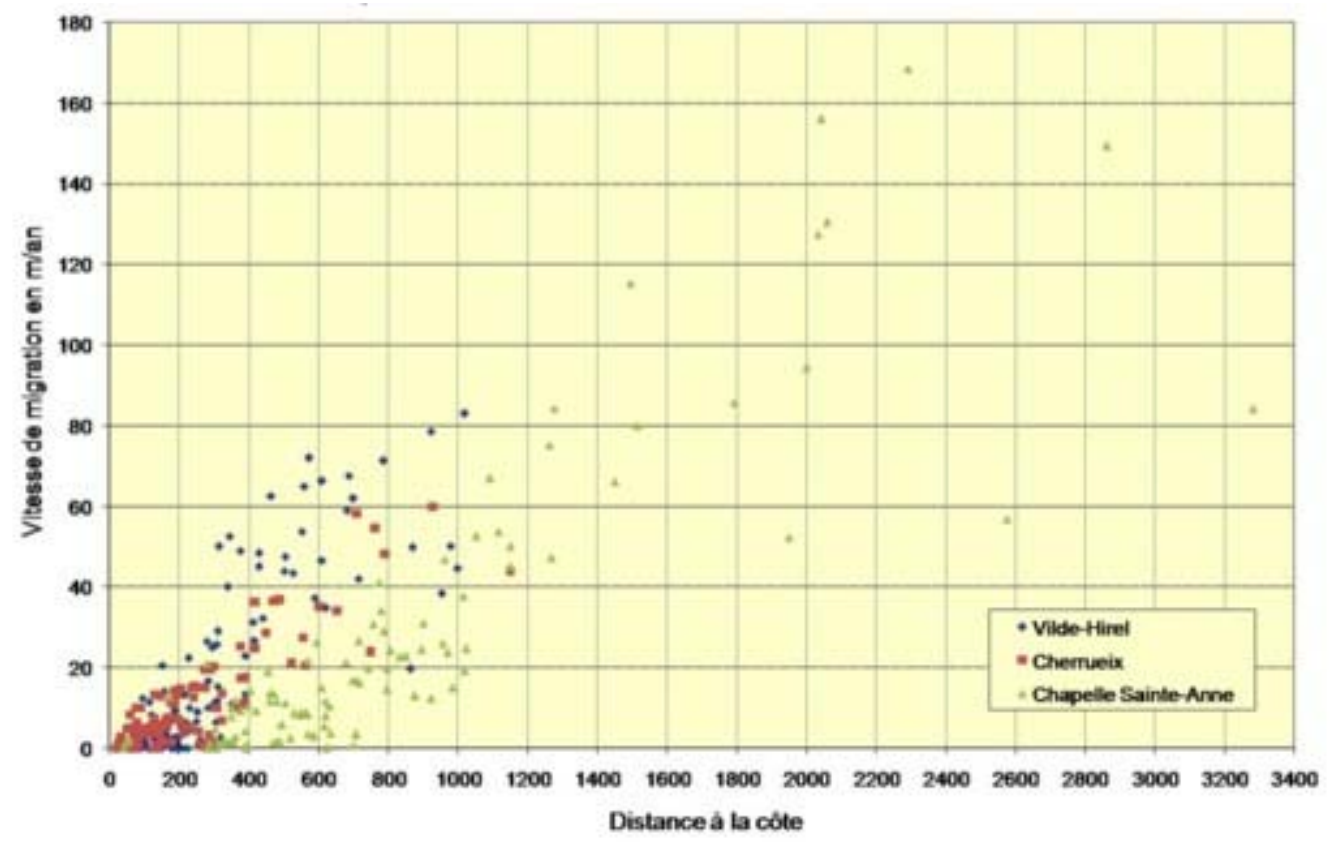

Figure 9. Migration rates of the shell banks as a function of their distance to the shore.

The formation and evolution of the bioclastic coastal bar - back bar mudflat system depend on the potential duration of wave action on the upper tidal flat and hence on the 
tidal submergence levels. On the lower and middle tidal flat, the flattened carbonate bioclasts with a high bearing capacity (WEILL, 2010) are easily set in motion by a light swell and migrate rapidly on the alumino-silicate sandy-silty tidal flat. When the shell banks reach the upper tidal flat, they accumulate on the spot and thicken sufficiently to form a coastal barrier, which isolates a sheltered micro-lagoon behind it where fine silt is deposited and gradually colonized by halophilic vegetation. At this stage, the waves can no longer wash over the crest of the bank, which stops migrating and stabilizes. When a strong swell is combined with high water spring tides, the banks at the edge of the salt marsh can be reworked by wash over processes, with the formation of overflow lobes migrating toward the lagoon behind the bank (WEILL et al. 2011). The mobilization of bioclastic components by the swell depends on submergence, and "gentle" waves tend to build up the coastal barrier. Conversely, a strong swell combined with high water spring tides may breach and destroy the structure of the coastal barrier.

\section{Hydro-sedimentary processes and the evolution of salt marshes around Mont- Saint-Michel}

4.1 Interaction between vegetation and sedimentation and the establishment of salt $\underline{\text { marshes }}$

In the western part of Mont-Saint-Michel bay, the salt marshes are most developed beyond La Chapelle Sainte-Anne and extend over almost $3 \mathrm{~km}$ on the upper tidal flat around Mont-Saint-Michel itself (LEFEUVRE et al., 1996). Deposition of sediments at the salt marsh front around Mont-Saint-Michel depends mainly on the duration of submergence and hence on the elevation of the salt marsh front, on the morphosedimentary context of the salt marsh front and on the level of the salt marsh or the mudflat itself.

The sedimentary accretion at the salt marsh front (BONNOT-COURTOIS and LEVASSEUR, 2002) varies according to the morpho-dynamic context of the upper mud flat. In calm conditions, fine particles are deposited at a rate of 1 to $2 \mathrm{~cm} /$ year at the boundary between the lower salt marsh and the upper mud flat. The more exposed salt marsh fronts located in dynamic conditions may be subject to erosion, often linked to the proximity of a channel (the edge of the salt marsh can retreat by almost $20 \mathrm{~m}$ in one year) and the upper mudflat sectors located downstream from the moving sand recover large quantities of sediment, sometimes reaching $10 \mathrm{~cm} /$ year. Sedimentary accretion diminishes from the upper mud flat to the middle and upper salt marsh, where it stands at only a few $\mathrm{mm} /$ year. This reinforces the reverse gradient of the salt marsh. As plant species take hold according to their tolerance to submergence, the distribution of salt marsh plant formations can be directly linked to the topography drawn from the Lidar survey (figures $10 \mathrm{a}$ and $\mathrm{b}$ ). Sedimentary accretion is generally significant on the upper mudflat. First of all, the sediment settles and when its elevation reaches a certain level above sea, pioneer plant 
species start to grow. The durability of a salt marsh and the dynamics of its progression directly depend on the hydro-sedimentary context of the upper mudflat.

The settling and propagation of a salt marsh is directly related to favorable conditions which are essentially:

- an elevation compatible with the resistance to submergence (cyclic and of accumulated duration) of primary perennial colonial species.

- a morpho-sedimentary and hydrodynamic context favorable to the implantation of seeds and the maintenance of the protected conditions required for the survival of young plants after germination.

In general, salt marsh build-up follows the sequence below (BONNOT-COURTOIS and LEVASSEUR, 2012) (figure 11):

1) Initiation or edification: one of two conditions (or both if possible) is required to trigger this phase. The elevation must be suitable and the exposure mode must be at least semi-protected.

2) Consolidation: interaction between pioneer species (i.e. Alkali grass and p.p. Cordgrass) and sedimentation at the salt marsh front result in the build-up of small mounds which then coalesce. Puccinellia maritima becomes dominant, but this phase is still marked by the presence of upper mudflat species.

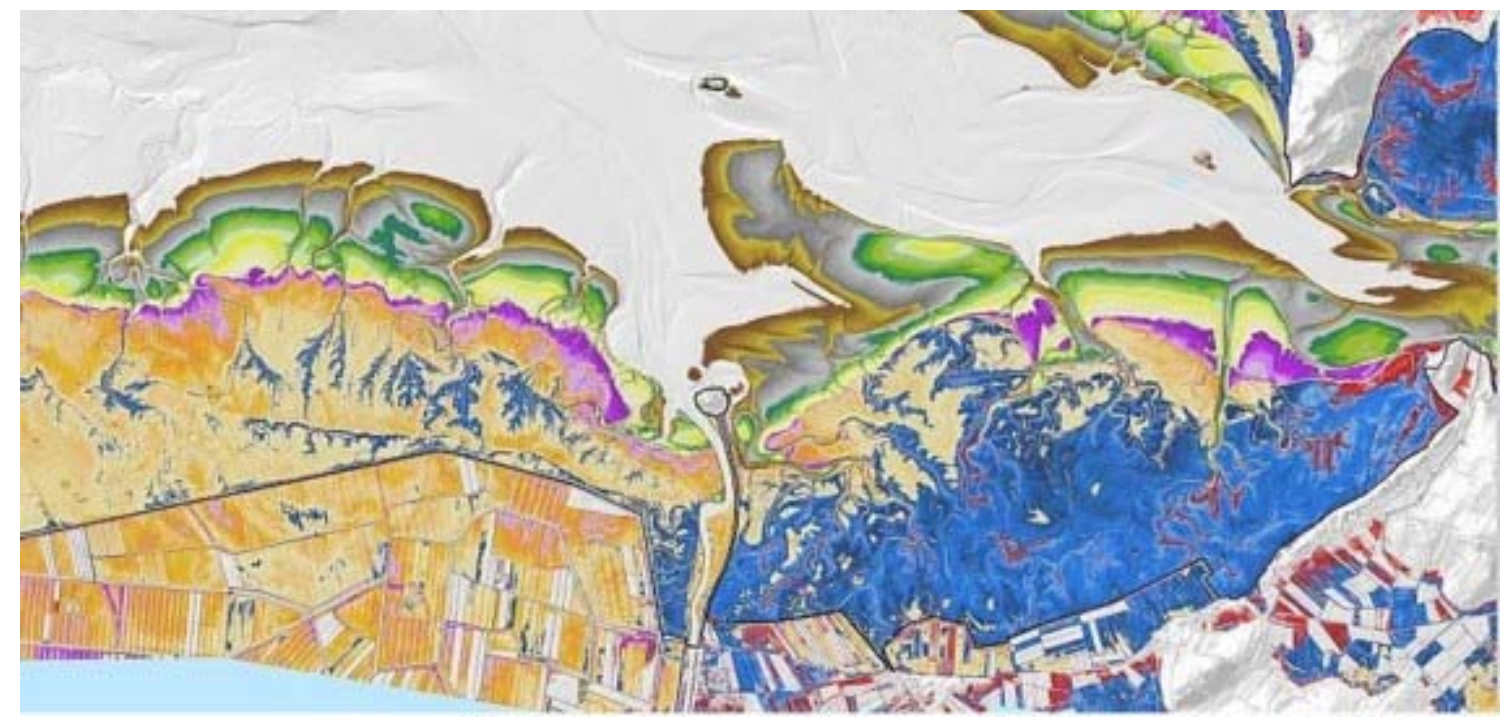

Figure 10 a. Topography of the salt marshes around Mont-Saint-Michel (LIDAR survey 2002).

3) Maturing: the surface of the marsh stabilizes, enabling Atriplex portulacoides (Atriplex) shrubs to become dominant. This species can remain over many years as 
Intertidal sedimentary dynamics in Mont-Saint-Michel bay, a study of its natural evolution and man-made modifications: n02.15

long as it is not altered by external, frequently anthropogenic disturbances (LEFEUVRE et al. 2009).

4) Continentalization concludes this sequence. This phase is characterized by the development of grassland vegetation on areas almost out of reach of the tides, with a great potential for development (Couch grass and Fescue). In comparison with 1999 (figure $10 \mathrm{~b}$ ), Couch grass has developed spectacularly, covering 73\% of the upper and middle salt marsh to the west of Mont-Saint-Michel (LEFEUVRE et al. 2009).

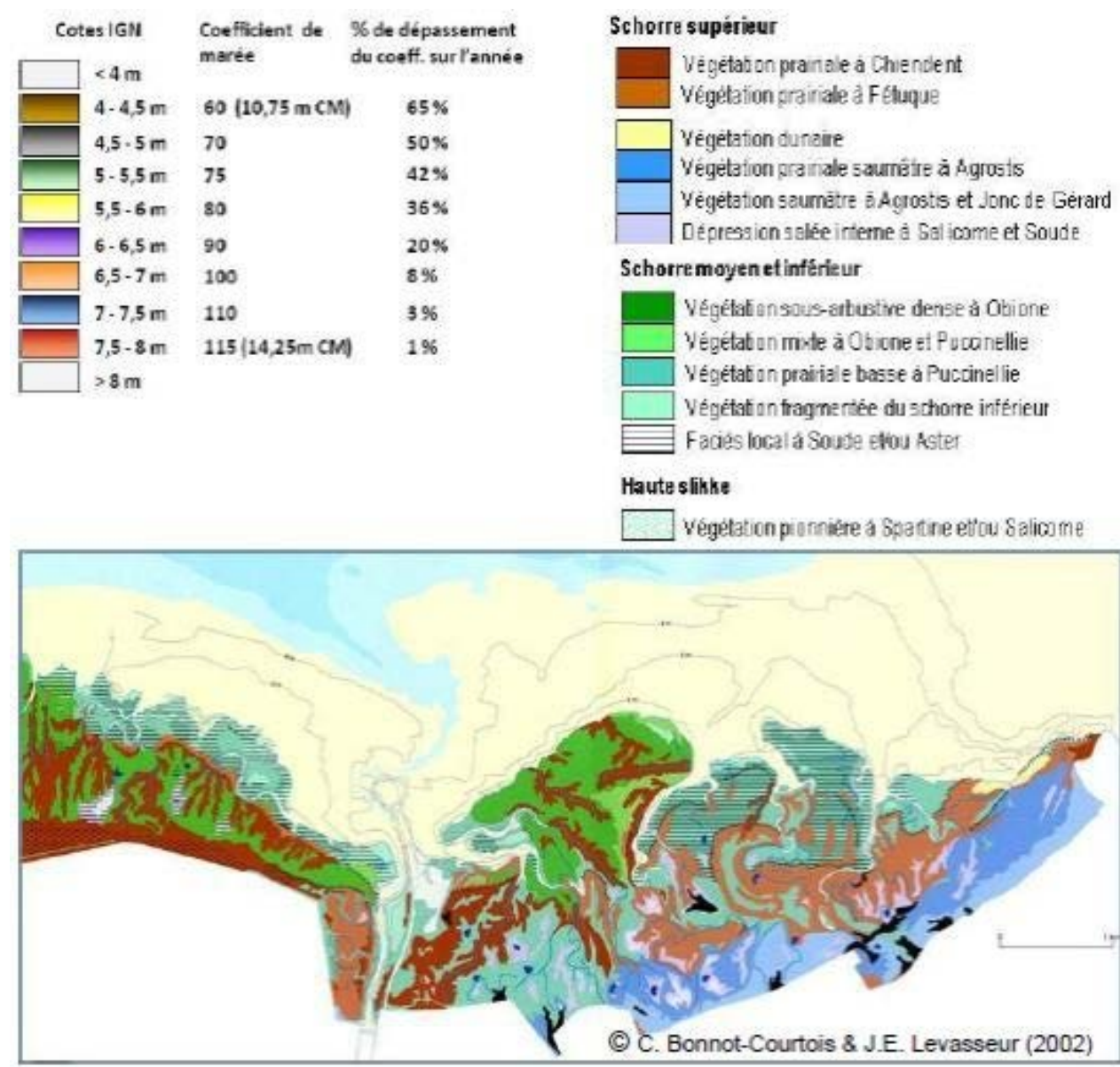

Figure 10 b. Distribution of the salt-marsh plant formations around Mont-Saint-Michel (condition in 1999). 


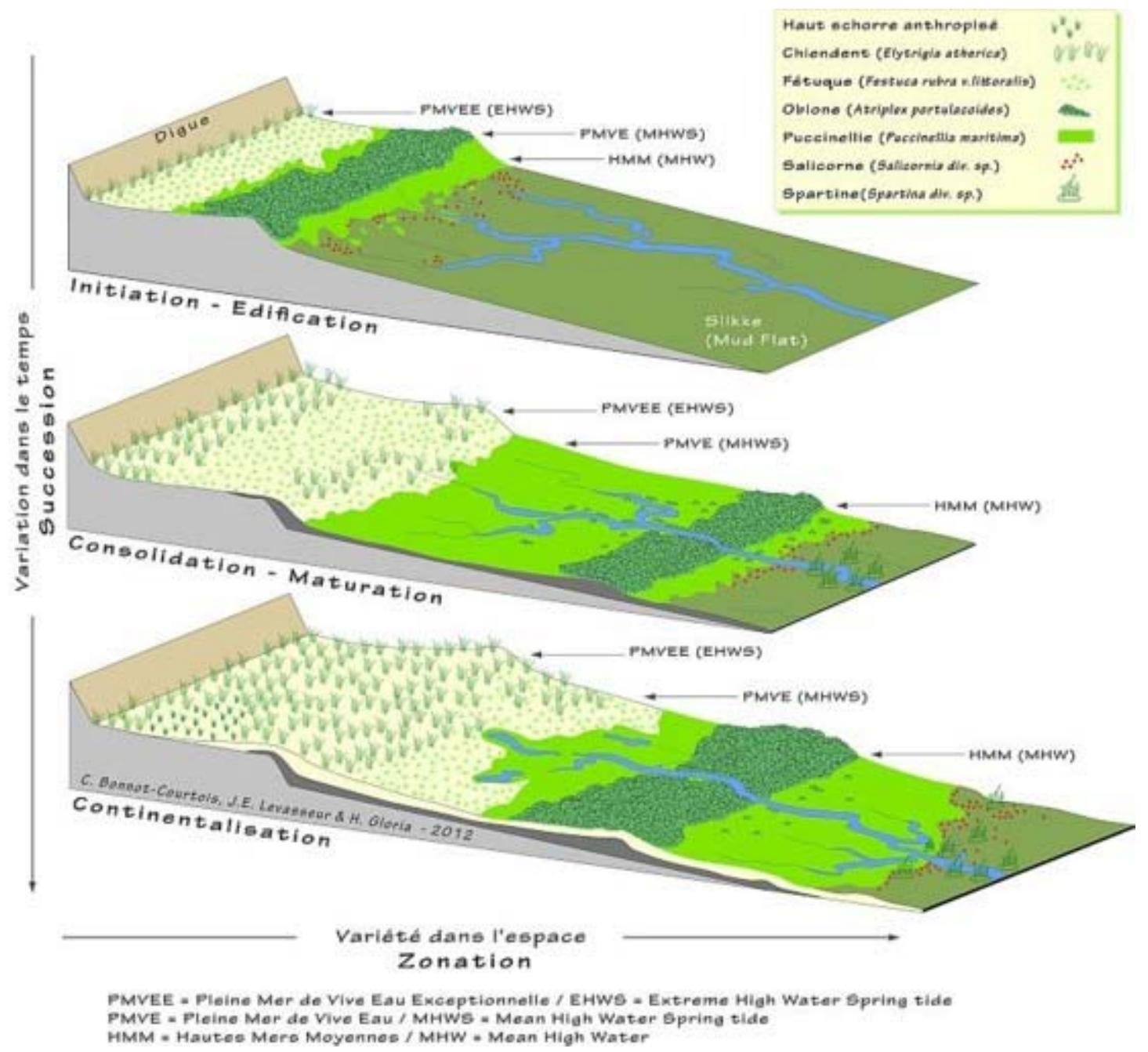

Figure 11. The different phases of evolution of a salt marsh (BONNOT-COURTOIS \& LEVASSEUR, 2012).

\subsection{Evolution of the salt marshes (figure 12)}

Analysis of a chronological set of aerial photographs (14 assignments performed at fiveyear intervals on average) between 1947 and 2005 shows that the area covered by salt marshes to the west of Mont-Saint-Michel has doubled in 50 years (654 ha in 1947 and 1,366 ha in 1996), while they have progressed more slowly to the east (634 ha in 1947 and 1,049 ha in 1996).

Salt marsh progression is not the same in all sectors around Mont-Saint-Michel. The central part of the western salt marshes (sector B) and the right bank of the Couesnon (sector D) have changed very little, with the continuous vegetation mat advancing slowly and steadily. The La Chapelle Sainte-Anne sector (sector A) did not change significantly until 1990, then prograded more rapidly due to aggradation of the sandbanks, creating sheltered conditions favorable to the development of pioneer halophilic vegetation on the upper mudflat. The salt marsh on the left bank of the 
Couesnon (sector C) has progressed rapidly and steadily, growing from 150 ha in 1947 to 700 ha in 2005. Finally, to the east of Mont-Saint-Michel, the salt marshes in the Great Bank (sector E) and Roche Torin (sector F) zones advanced considerably between 1947 and 1980, subsequently slowing down until 2005. The salt marshes currently cover almost 2,500 ha between La Chapelle Sainte-Anne and the Pointe de Roche Torin, advancing on average around 15 to 20 ha per year.

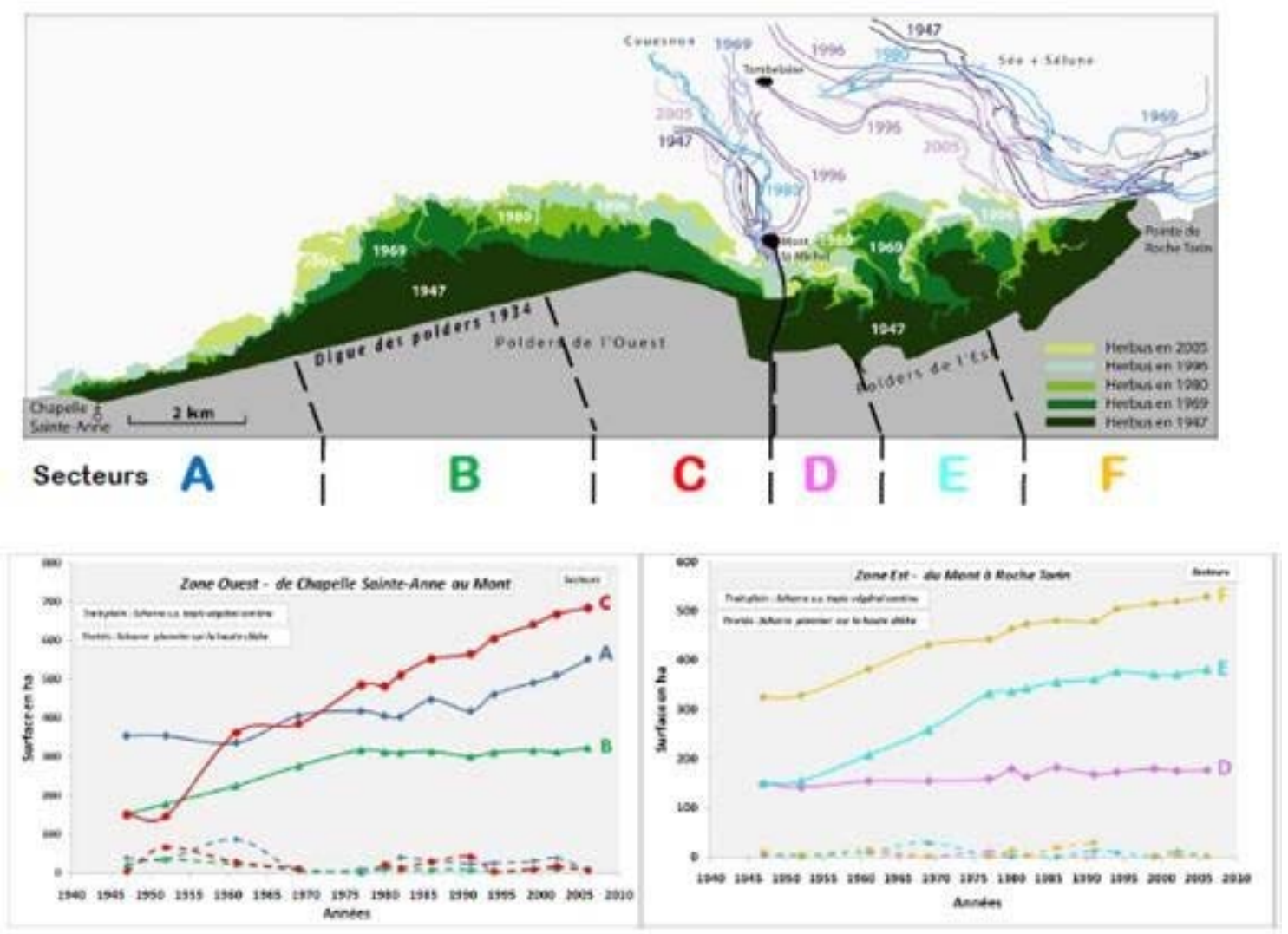

Fig. 12. Progression and evolution of the salt marsh surface area between 1947 and 2005.

\section{Evolution of the landscapes and man-made modifications}

An ancient basement of metamorphic formations (570 million years old) and of granite bodies (540 and 525 million years old) form the substratum and the relief surrounding Mont-Saint-Michel bay (L'HOMER et al. 1999). The current configuration of the bay results from the sea level rise following the last deglaciation 18,000 years BP. The Holocene transgression included an initial phase marked by a rapid rise in sea level, from $-120 \mathrm{~m}$ to $-10 \mathrm{~m}$ below the present-day sea level from 18,000 years BP to 6,000 years BP (10 mm/year), followed by a slower second phase with the sea level rising at an average rate of $1.5 \mathrm{~mm} /$ year (FAIRBANKS, 1989 in BILLEAUD 2007). This overall rise in sea level did not take place steadily, but through a sequence of positive or negative oscillations causing the shoreline to advance and retreat (MORZADEC- 
KERFOURN, 1975, 2002). As from 8,000 years BP, the sea flooded the bay and the bottom of the estuaries and the Dol marsh were gradually filled with sedimentary deposits. The thickness of the deposits in the Holocene sedimentary prism exceeds $15 \mathrm{~m}$ in places.

\subsection{Historical evolution of the landscapes of the bay}

The historical evolution of the landscapes of the bay was extensively studied by Alain L'HOMER and was set out in a paper entitled "Evolution of the bay around Mont-SaintMichel since 708" for the Abbey's 13 ${ }^{\text {th }}$ centenary (L'HOMER et al. 2009). The maps below trace the major phases in the formation of the bay's coastline and are approximate reconstructions for the oldest periods prior to the $18^{\text {th }}$ century. The lack of data on the period around year 708, when Mont-Saint-Michel was founded, has made it necessary to go back to the end of the Roman Empire in order to obtain an initial cartographic basis (figure 13).

Archaeological finds in the different sedimentary contexts constitute markers of human occupation in the Dol marsh, going back to the end of the Gallic period (BIZIENJAGLIN, $2002 \&$ 2008). Following heavy fighting involving three Roman legions in the area of Avranches in $56 \mathrm{BC}$, the four Gallic tribes living near the bay were finally integrated into the Roman Empire from 51 BC onward (J-Y COCAIGN, oral communication). Major roads, set back from the coast, cross or converge on Legedia (Avranches). Coastal tracks to the south and the north, serve the drying ports generally located at the mouths of the rivers.

The coastal sandbars to the south-west gradually formed a border to the salt meadows. Although crossed at regular intervals by a number of small coastal streams that drain the hinterland, these sandbars restrict the inflow of seawater into the black marshes in the south of the bay. This configuration of the tidal flat was favorable to the establishment of salt-boilers' workshops in the Dol marsh, particularly at Roz-sur-Couesnon, Hirel, La Fresnais and Saint-Méloir-des-Ondes. These salt production sites range from the $1^{\text {st }}$ century BC to the $4^{\text {th }}$ century AD (L'HOMER \& PIQUOIS, 2002). In the Dol marsh, this type of salt production ceased following a rapid rise in sea level from the middle of the $3^{\text {rd }}$ century. Apart from salt production, the development of marine resources left little trace (J.Y. COCAIGN, oral communication). Only a few landing beaches have been reported at Cancale and on the estuarine salt flats, subject to the shifting courses of the rivers and major currents.

The wooden remains of a fish dam dated over 3,450 years BP (the end of the Bronze Age) (L'HOMER, 1995) were discovered at Saint-Jean-le-Thomas during a major erosion phase which resulted in a down wasting of the tidal flat. The wooden or stone fisheries at the foot of the Champeaux cliffs are evidence of major fishing activities in very ancient times. The cliff site includes the remains of nine stone dams dating from the $6^{\text {th }}$ to the $9^{\text {th }}$ century. These installations rapidly silted up and were gradually moved 
westward between the $6^{\text {th }}$ and the $12^{\text {th }}$ century (BILLARD et al. 2006; BILLARD et al. 2012).

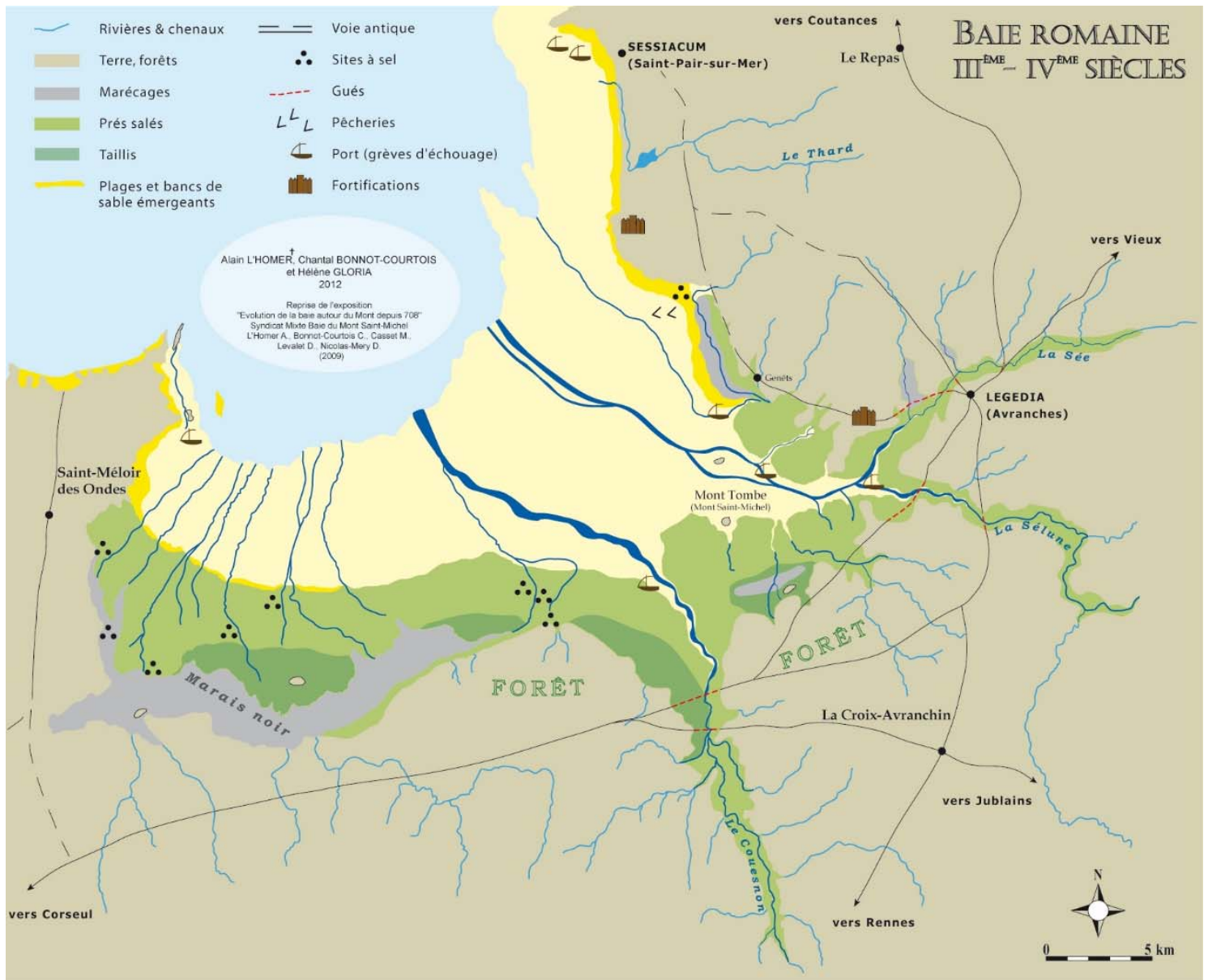

Figure 13. Reconstruction of the shorelines during Roman times (L'HOMER, 2008).

The history of the bay from the $8^{\text {th }}$ to the $10^{\text {th }}$ century is closely linked to that of the Mont-Saint-Michel abbey, initially a simple oratory founded in 708 by Aubert, the Bishop of Avranches at the time. Contrary to the interpretation of a $15^{\text {th }}$ century monk suggesting that the Scissy Forest had been destroyed by a tidal wave when the sanctuary was founded in 709, there was no forest before this date around Mont-Saint-Michel, although there are still extensive woodlands, in particular in the southern part of the bay (BIZIEN-JAGLIN \& L'HOMER, 2008).

In addition to the numerous coastal rivers draining the southern section of the Dol marsh, sandbars and shell banks increasingly restrict the inflow of seawater. The earliest settlements were established on the main bar nearest to the open sea. Since the $8^{\text {th }}$ century, the estuarine bay located between the Couesnon, Sée and Sélune estuaries became a major salt-producing centre as a result of two technological advances. Extraction and washing of the salty sand found on the estuarine bay beaches initially 
contributed to the first increase in available brine. This brine was then heated in large metal receptacles, considerably improving the productivity. Salt production in the bay also benefited during this period - and up to about 1150 - from very favorable climatic conditions (J.-Y. COCAIGN, oral communication).

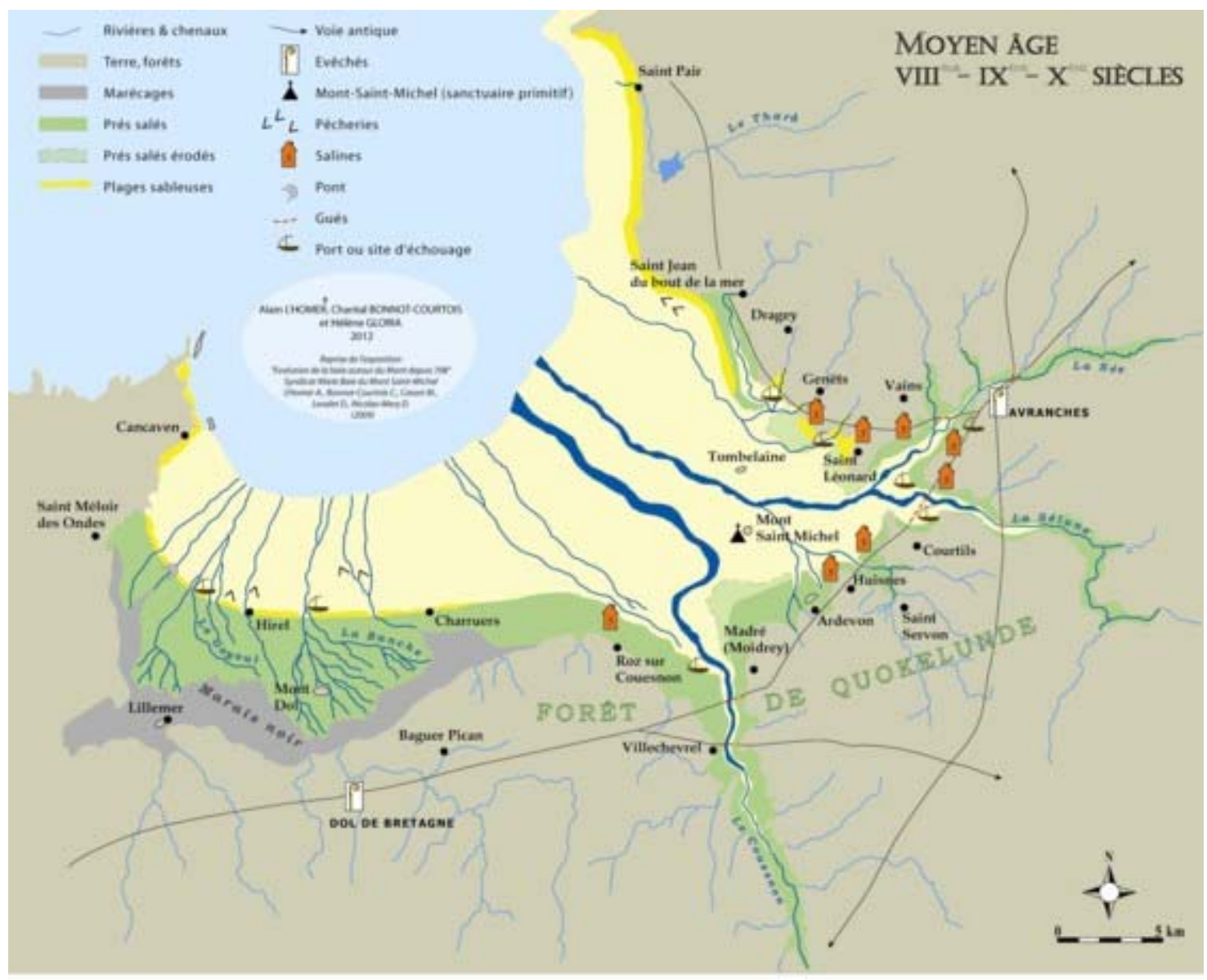

Figure 14. The shores of the bay during the Middle Ages. Establishment of salt works and marine activities (fisheries, ports).

Between the $10^{\text {th }}$ and the $12^{\text {th }}$ centuries coastal villages such as Hirel and Cherrueix were founded on the sandbar partially cutting off the Dol marsh. The establishment of these two parishes, reported for the first time in 1181, undoubtedly coincided with the building of a dike to raise the sandbar. However, seawater continued to find its way in, particularly via the mouths of the coastal rivers, until the $12^{\text {th }}$ century. Fields enclosed by small dikes (verdières) have been reported to the west of Hirel in the marshes protected by this dike. The weakest point which prevented the complete enclosure of the Dol marsh for centuries is located to the east between Cherrueix and the Saint-Broladre cliffs. In this sector, unlike in the south-western part of the bay, the sedimentary dynamics and the shifting course of the Couesnon prevented the sustainable build-up of 
the coastal sandbars. Numerous unsuccessful attempts to build dikes to enclose the verdières on these fertile white marshes (JORET, 2008) were made during this and subsequent periods. From the $12^{\text {th }}$ century onward, a number of rural establishments and even the parish of Paluel were founded, but subsequently destroyed by the combined action of tides and the shifting course of the Couesnon.

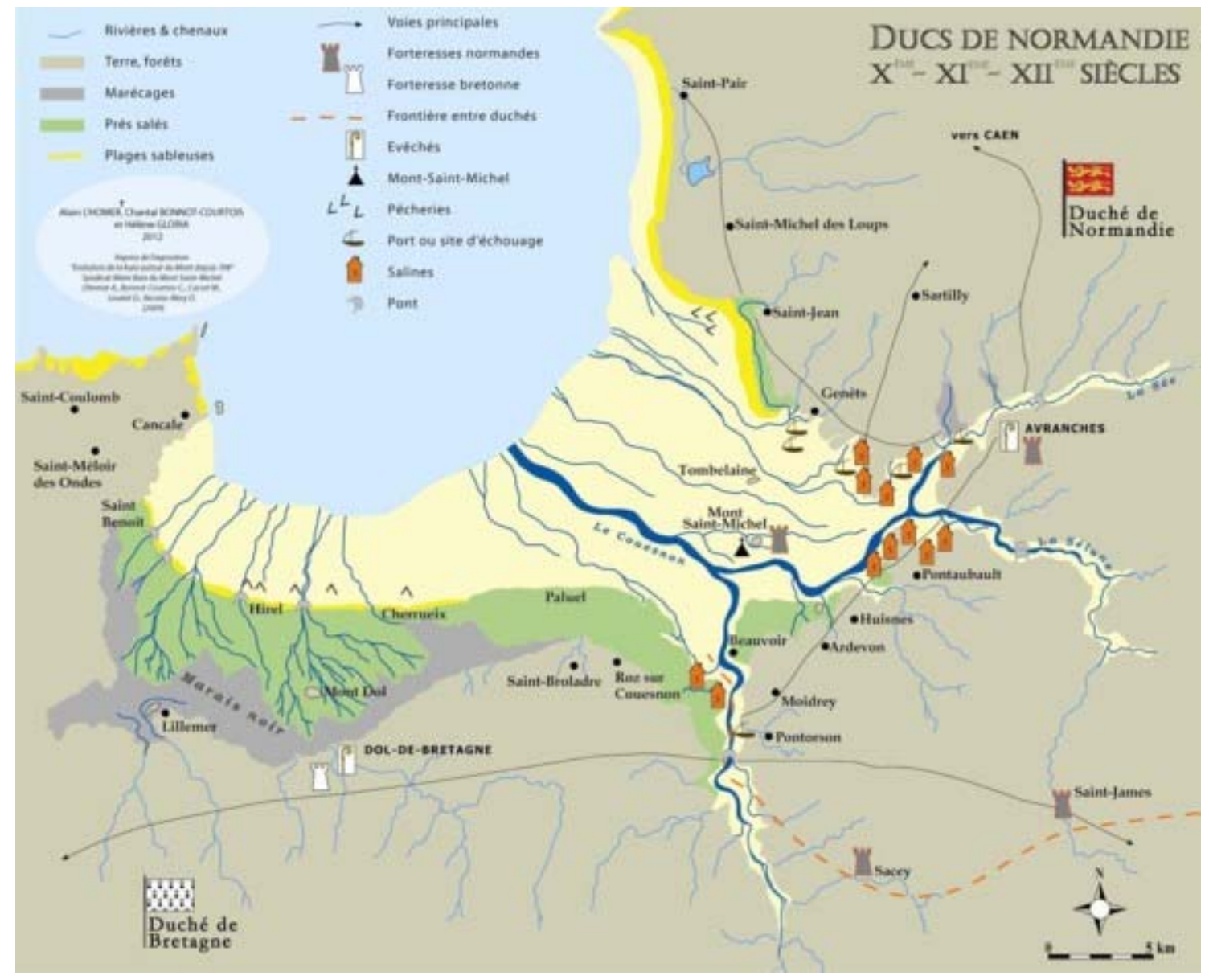

Figure 15. The shores of the bay around the $11^{\text {th }}$ century.

The relative stability of the tidal flats to the south-west and north-east of the bay led to the installation of many fisheries. Taking advantage of the schistose shoals and cliffs, several stone fisheries were built at the bottom of the Saint-Jean cliffs. These installations were then moved toward the north-west, particularly in the $10^{\text {th }}$ and $11^{\text {th }}$ centuries. The cliff site was abandoned in favor of the Sol Roc site, where two generations of fisheries were found: the one currently covered by hermella dates back to the $12^{\text {th }}-13^{\text {th }}$ century and was abandoned in the $15^{\text {th }}$ century in favor of another installation nearer the coast (BILLARD, oral communication). On the tidal sand flats of the south-west, the technique of using wooden fisheries took precedence, and an initial group of fisheries to the west dates back to earlier than the $11^{\text {th }}$ century. Opposite Vildé 
la Marine, some of the present-day fisheries go back to the $13^{\text {th }}$ century when the first ones were abandoned (LANGOUET, 1995).

Between the $10^{\text {th }}$ and the $12^{\text {th }}$ centuries and later, more and more salt works were established in the estuarine bay. The sand taken from the tidal flat and desalinated by washing was gradually piled up near the salt works and, until the $19^{\text {th }}$ century, contributed to the creation of huge and often high sandy dikes called mondrins. The shoreline of the estuarine bay was then definitively changed, as the marshes were protected from marine incursion by these accumulations of calcareous mud (figure 16).

Two successive barriers isolated the Dol marsh from the coastal domain during the Middle Ages (figure 17). The oldest, internal bar was breached in many places, probably related to major seawater incursions into the marsh. The build-up of this first bar dates back to the $6^{\text {th }}$ century and continued until the $8^{\text {th }}$ century (L'HOMER et al. 1995). The second bar formed from the $9^{\text {th }}$ century, when numerous marine submergences appear to have occurred.

The Duchesse Anne dike, built on this second line of ancient shell bars, fixed the coastline and isolated the Dol marsh from marine incursions. The topographical level of the marsh is lower on the upper tidal flat and, as the gradient of the marsh is reversed, the innermost parts of the black marsh are $4 \mathrm{~m}$ lower than the white marsh, which in turn is 1 to $2 \mathrm{~m}$ lower than the present-day upper tidal flat.

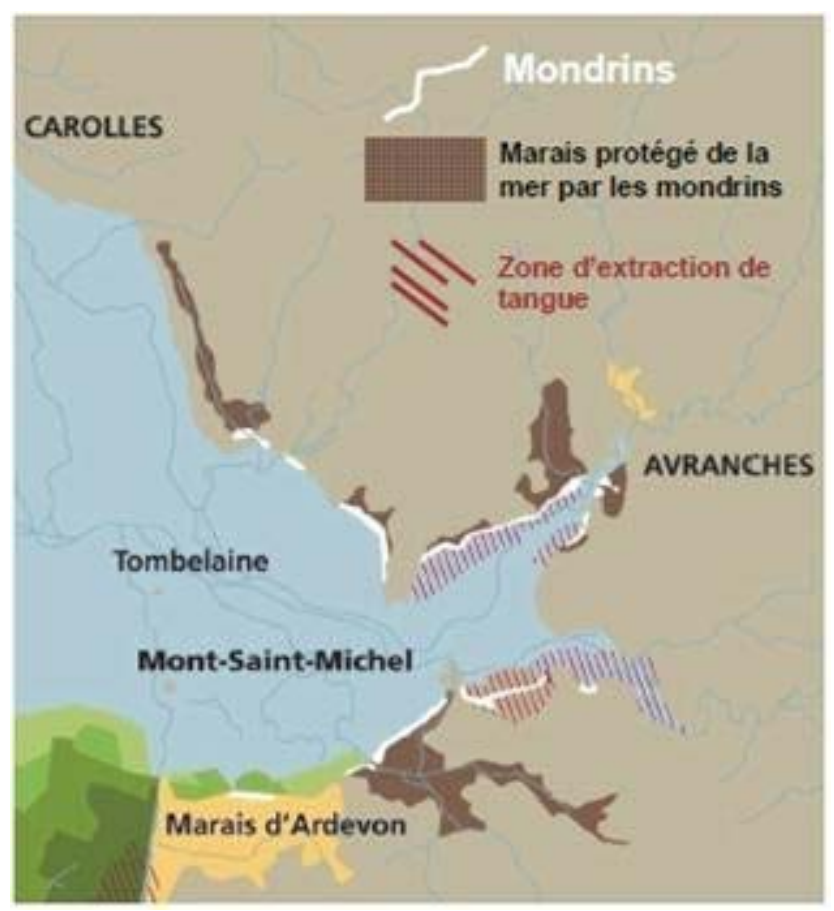

Figure 16. Mondrins, or ancient accumulations of sand, related to salt production at Avranchin that protect the marshes from marine incursion (Extract from the exhibition entitled "The bay through the ages" - Mont-Saint-Michel bay Ecomuseum - CG50" J.Y. COCAIGN, personal communication) 
Intertidal sedimentary dynamics in Mont-Saint-Michel bay, a study of its natural evolution and man-made modifications: n02.23

At the end of the $18^{\text {th }}$ century, the maps, drawn by the Cassini family on the King's orders, constituted the first general map of the whole of France. It comprises 181 sheets representing land surveyed between 1756 and 1789. Sheet No. 127, published in 1759, covers the coast between Saint-Malo and Granville and shows Mont-Saint-Michel bay uncovered for the most part and crossed by several main channels. To the west, two river mouths at Saint-Benoît-des-Ondes and Le Vivier-sur-Mer correspond to the junction of small coastal rivers flowing along a straight line to the north. The mouths of the three main rivers of the bay are located to the east: the Couesnon, the Sée and the Sélune, which flow in a north-westerly direction. Before the modifications around Mont-Saint-Michel were made, the tide rose into a large estuarine system formed by the common channel of the Sée and Sélune and by that of the Couesnon (figure 18). The channels of these "wild" estuaries did sometimes shift with a potential displacement of up to $4 \mathrm{~km}$ on either side of the line from Mont-Saint-Michel to La Chapelle SainteAnne (L'HOMER, 2002).

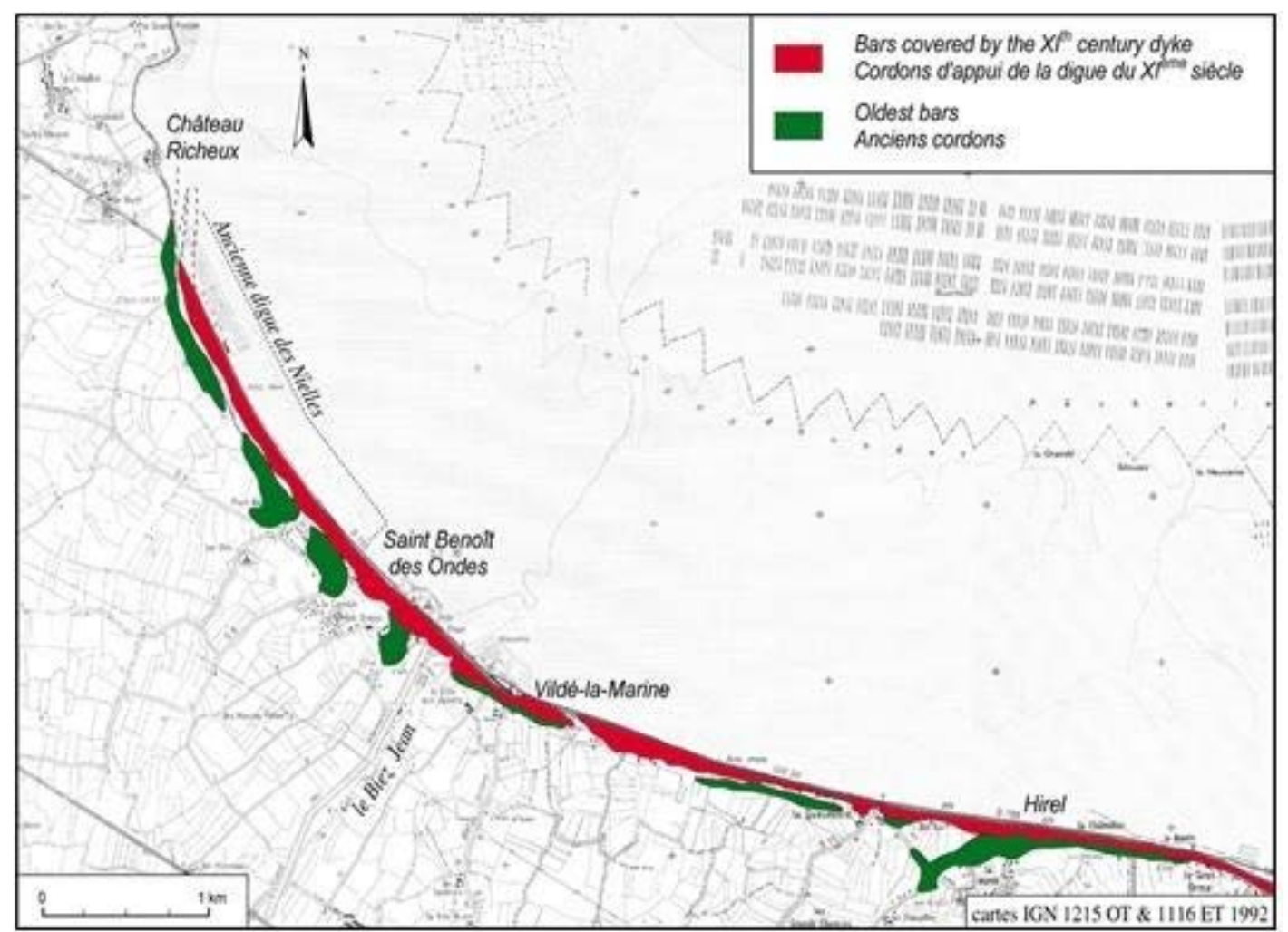

Figure 17. Ancient coastal conditions in the western part of the bay between Château Richeux and Hirel. 


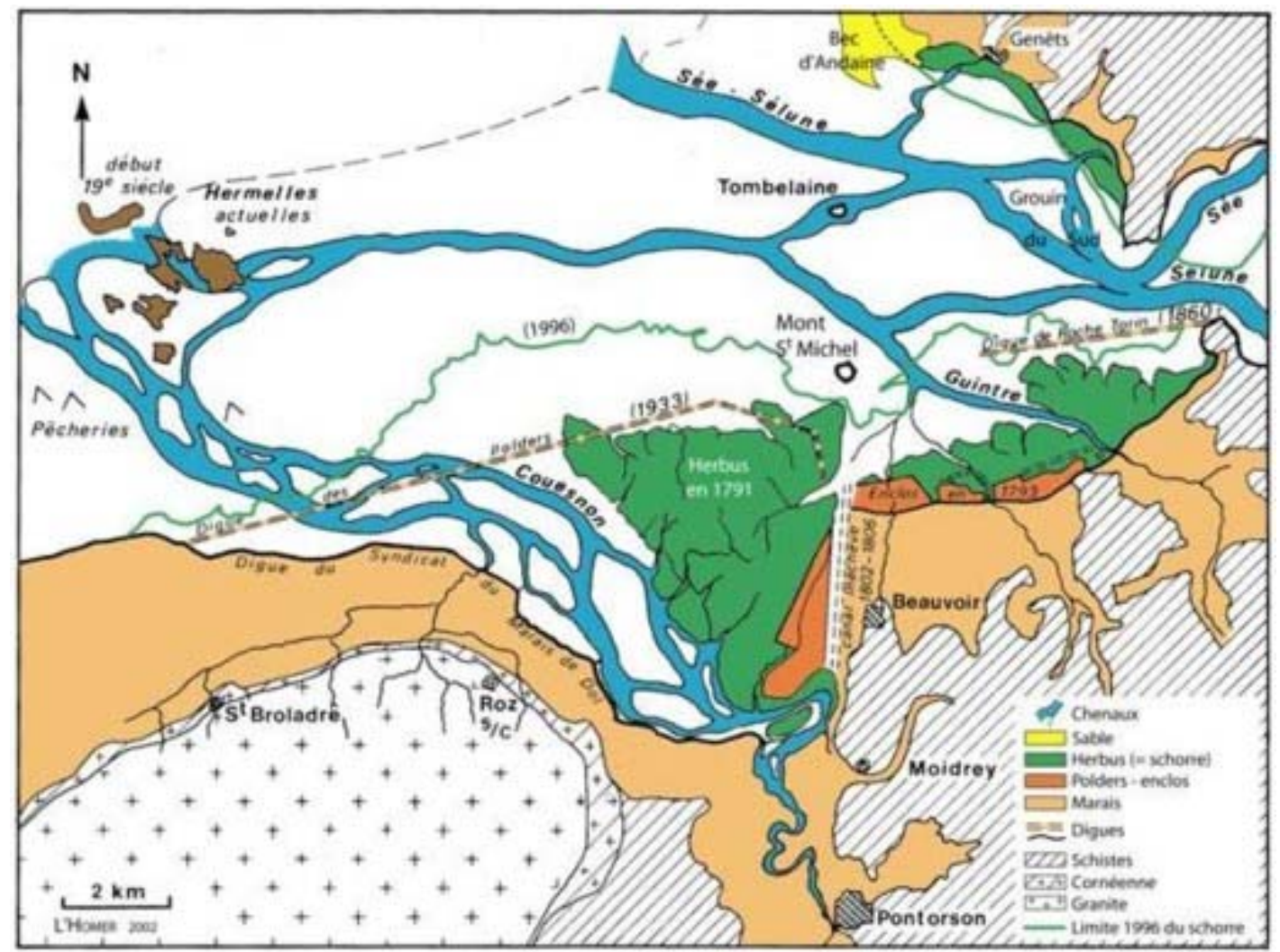

Figure 18. Configuration of the estuarine zone at the end of the $18^{\text {th }}$ century.

In 1771, the geographic engineers were given the task of drawing up "a topographic map of the French coastline... from Mont-Saint-Michel to the island of Noirmoutier". The accuracy of the surveys and the quality with which all the elements of the landscape were represented made this a valuable reference map for the coast of Brittany. The surveys in Mont-Saint-Michel bay were conducted in the spring of 1775 and the tidal levels, "high spring tides", are accurately indicated on the map. Immediately to the west of Mont-Saint-Michel, the vast expanse of land shown as "mollières or pastures covered by equinox tides" is a salt marsh which colonized the sediments accumulated on the right bank of the Couesnon. At its north-eastern extremity, the edge of the salt marsh is only $370 \mathrm{~m}$ from the Mont-Saint-Michel. To the south-east, next to the path leading from Pontorson to Mont-Saint-Michel itself, an enclosure surrounded by dikes was made at Beauvoir (figure 18). The Couesnon flows into the bay at La Chapelle SainteAnne (JORET, 2008) and then to the north-west in direction of the hermella bank. From Moidrey cove, the channel runs alongside the dike of the Dol Marsh Association, which protects the marsh at the foot of the granite mass of Saint-Broladre. In the estuarine zone, the channels of the Sée, the Sélune and the small watercourses between MontSaint-Michel and the Pointe de Roche Torin (the Guintre, the Landais and the Rive) meander significantly as they cross the tidal flats surrounding Mont-Saint-Michel and the Tombelaine islet (figure 20). 


\subsection{Modifications since the $18^{\text {th }}$ century}

\subsubsection{Fisheries}

In the western part of the bay, the almost continuous line of wooden fisheries became denser during the $17^{\text {th }}$ century, and the number of fisheries reached about 40 across the entire middle tidal flat. Expansion to the east was limited by strong tidal currents and the shifting of the Couesnon, which at the time flowed toward the north-west.

The role of these installations played in trapping sediments is clearly visible from the difference in elevation between the area enclosed and the tidal flats outside. These fisheries are found in low waters of coefficient 40 to 50 , i.e. on average $4.5 \mathrm{~m}$ above chart datum (-2.5 m IGN) (figure 9).

Operation of the old stone fisheries at Champeaux also led to significant accumulations of sediment inside the fish dams, as at the time there was no movable gate to allow drainage and erosion by the ebb tidal currents (BILLARD, 2012).
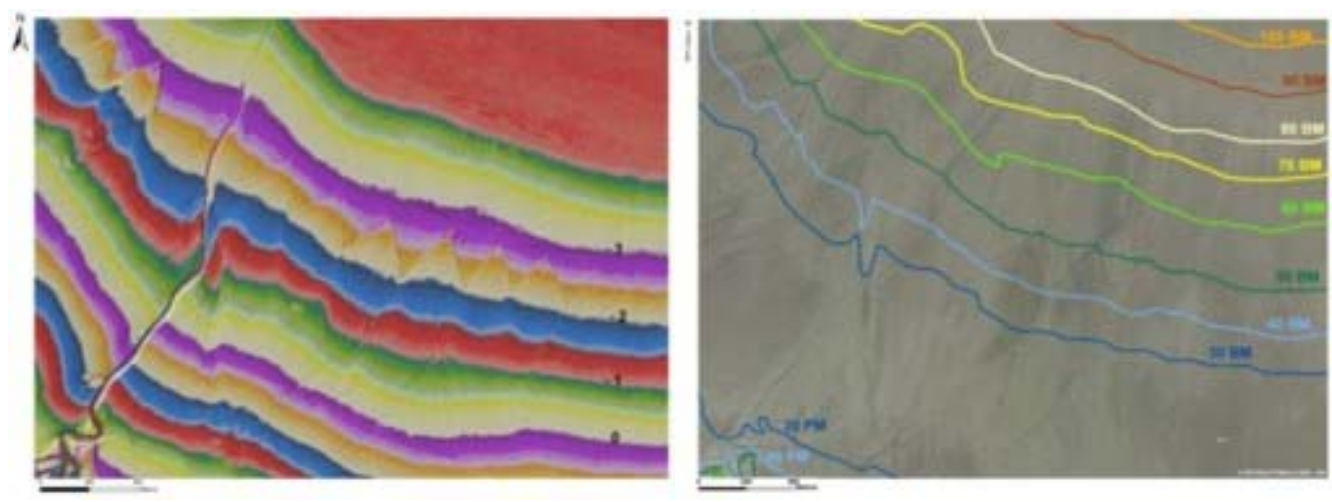

Figure 19. LIDAR topography and tidal levels near the fisheries at Vildé la Marine

\subsubsection{Shellfish farming (figure 20)}

The main stages of oyster farming development in Mont-Saint-Michel bay are as follows:

$18^{\text {th }}$ century: exploitation of natural common oyster beds by dredging,

$19^{\text {th }}$ century: farming of common oysters at Cancale,

1906: first intertidal oyster leases in uncovered areas on the middle and lower tidal flats at Cancale,

1959: introduction of the Portuguese oyster, followed by the Japanese oyster,

1970 to 1996: new deep-water oyster leases (figure 20).

The main impact of farming oysters in bags on trestles for the leases in uncovered areas was to slow down the currents and raise the level of fine silt under the installations (SORNIN, 1981; NIKODIC, 1981). During the shellfish-farming restructuring process 
of 2004, the most silt-laden oyster farms were transferred eastward in the place of the mussel beds opposite Vildé.

Mussel farming was introduced in the bay in 1954 on either side of the Vivier channel by mussel farmers from the Aiguillon cove in the department of Charente (VERGER and LE VOT, 2002). From 1960 onward, the lines of mussel stockades spread extensively between the Biez Jean channel at Saint-Benoît-des-Ondes and the hermella bank. Exploitation of the mussel stockades further developed in 1977 with the use of amphibious boats.

Between 1975 and 1980, new mussel leases were created off the hermella bank, and in 2004 the Vildé mussel stockades, replaced by oyster trestles, were transferred to the North-East of the hermella bank in the shift zone of the estuarine channels (figure 20).

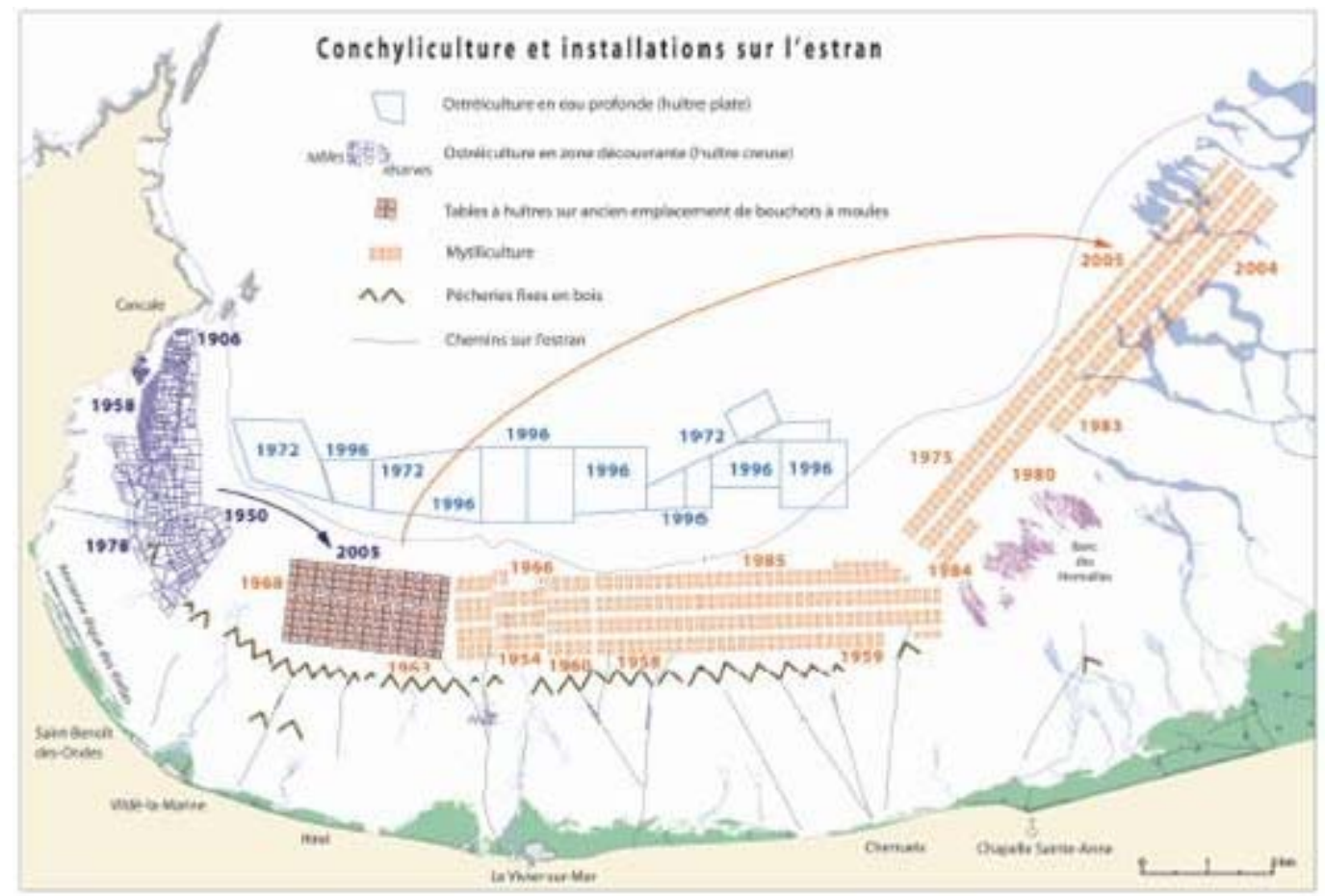

Figure 20. Shellfish farming and installations on the eastern tidal flat between Cancale and La Chapelle Sainte Anne.

The introduction of shellfish farming on the entire western lower tidal flat may have highly variable consequences on the sedimentation process. On the one hand, oyster farming on trestles causes silt deposition under the trestles. On the other hand, the density of the lines of mussel stockades tends to channel the currents, which are stronger between the stakes, but the production of bio-deposits increases the sediment's fine fraction content. The fixed fisheries of the middle tidal flat form traps where fine silt accumulates, particularly between Vivier la Marine and Le Vivier-sur-Mer. 
Intertidal sedimentary dynamics in Mont-Saint-Michel bay, a study of its natural evolution and man-made modifications: n02.27

\subsubsection{Dike building and land reclamation}

The process of reclaiming land from the sea by drying the marine marshes and surrounding them with dikes dates back to the $12^{\text {th }}$ century in the Dol marsh (BIZIENJAGLIN; 2008; JORET, 2008). To the west, the Duchesse Anne dike has fixed the coastline between Château Richeux and La Chapelle Sainte-Anne since the $11^{\text {th }}$ century. It extends eastward up to Moidrey in a succession of dikes, in places duplicated by counter-dikes and reinforced by spurs, which protect the Marsh at the foot of the SaintBroladre massif. The oldest of these were built before the $17^{\text {th }}$ century (SACHET, 2008).

The first dikes around Mont-Saint-Michel date from the end of the $18^{\text {th }}$ century (figure 21). The first dike projects, submitted in 1757 , encompassed a huge area of the tidal flat between the Moidrey cove, the Tombelaine islet and Roche Torin Point. In 1769, the Granville ship-owner Quinette de la Hogue requested a new, less ambitious dike project around Mont-Saint-Michel itself. In 1777, the Services of the Comte d'Artois (later to become Charles X) submitted a new project for concessions impinging on Mont-SaintMichel itself, to thwart the dike-building attempts by Quinette de la Hogue (figure 21).

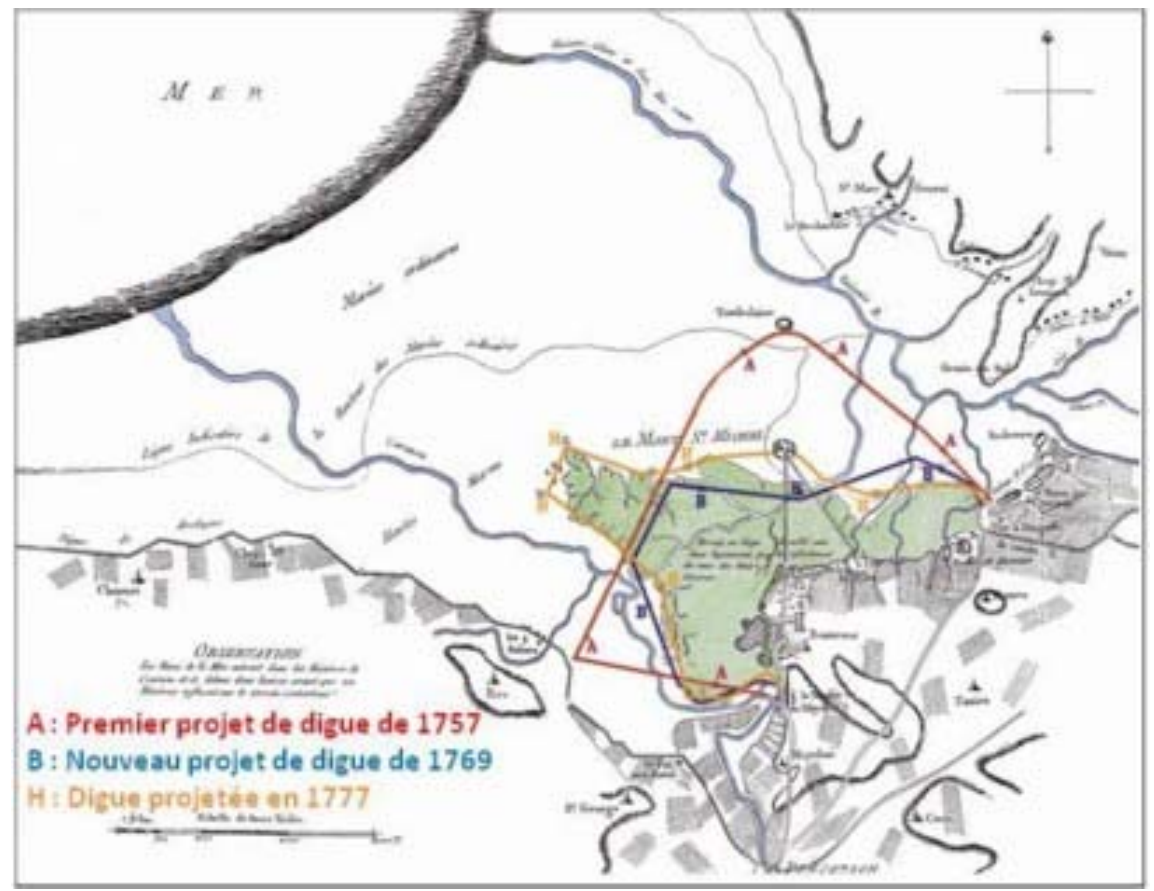

Figure 21. The first dike building projects around Mont-Saint-Michel.

At the very beginning of the $19^{\text {th }}$ century, the mouth of the Couesnon was located in Moidrey cove and the main channel flowed in a north-westerly direction alongside the dike of the marshes located below the Saint-Broladre massif. Periodically destabilized by tidal currents and sediment deposition, the Couesnon channel and the tidal channels alternately encroached on the rock-banked dikes of the Breton coast to the west between 
1805 and 1817, subsequently devastating the soil dikes of the recent enclosures on the Normandy coast near Mont-Saint-Michel between 1817 and 1833 (figure 22). A first attempt to channel the Couesnon in 1805 ended in failure.

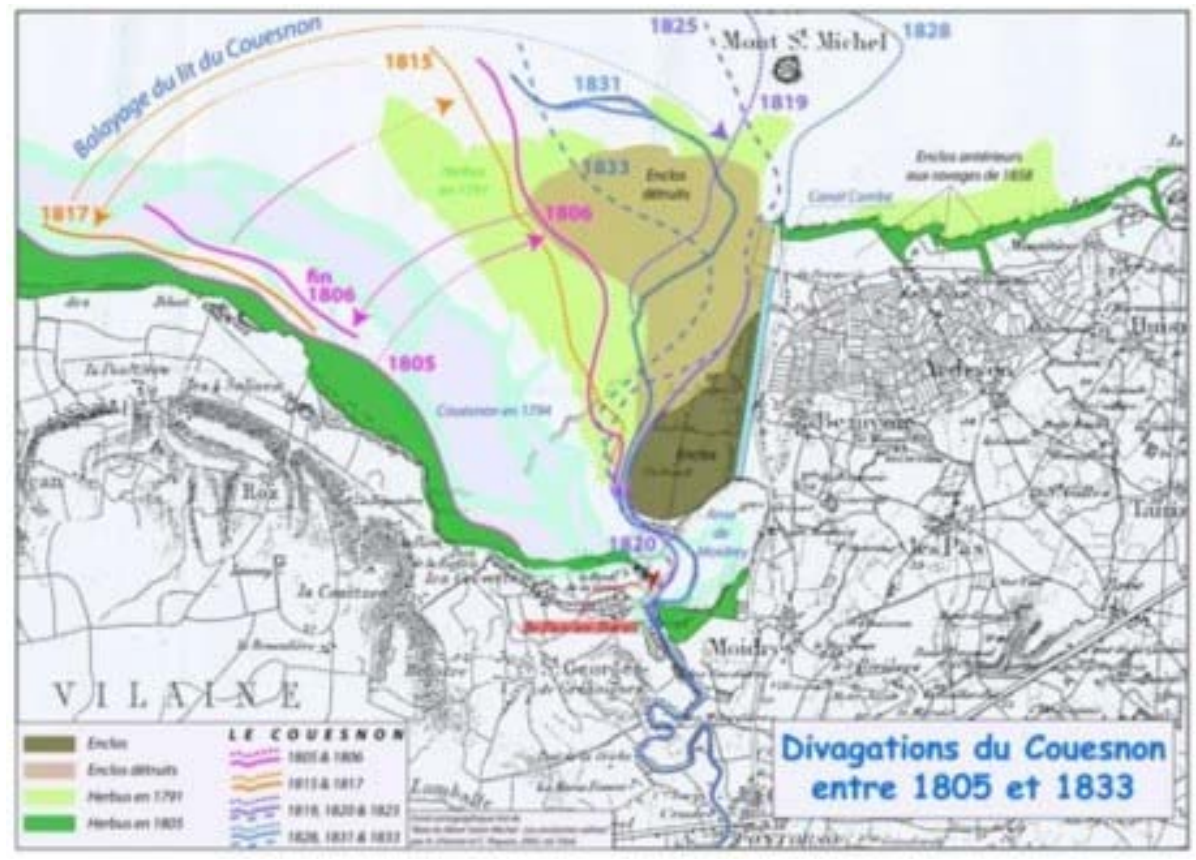

Figure 22. Meanders of the Couesnon at the beginning of the $19^{\text {th }}$ century before the river was channeled

During the first half of the $19^{\text {th }}$ century, the meanders of the Couesnon broke through the dikes in many places, destroying all the early enclosures. In 1856, a company named Mosselmann and Donon reached an agreement with the State to reclaim 4,350 ha around Mont-Saint-Michel as polders, with the company undertaking to channel the Couesnon.

The main phases of land reclamation occurred as follows:

1858: diversion of the Couesnon by Mosselmann by building an earth dam known as the "Pas-aux-bœufs" at Moidrey (figure 22),

1863: channeling of 3,800 $\mathrm{m}$ of the Couesnon, starting from the Moidrey cove,

1857-1861: construction of the Roche Torin dike impinging on the Roche Torin Point at the mouth of the Sélune, initially planned to extend up to Mont-Saint-Michel itself; this dike was to divert the common channel of the Sée and the Sélune northward in order to enable land reclamation to the east of Mont-Saint-Michel;

1867: the concession project to the east of Mont-Saint-Michel was abandoned due to difficulties created by the shifting of the channels; Mosselmann then became the West Polders Company, 
1868: the sea broke through the earth dikes and flooded the first polders to the west: following these storms, a recommendation was put forward to rock-bank the ring dike, 1878-1879: construction of the in submersible dike access road to Mont-Saint-Michel, 1879-1884: diversion of the small streams to the east of Mont-Saint-Michel (the Guintre, the Rive and the Landais),

1906, 1928 and 1947-49: land reclamation to the east of Mont-Saint-Michel,

1914: permission for southward displacement of the western polder concession limit, originally planned to extend up to Mont-Saint-Michel itself, obtained by the Beaux-Arts; 1933-1934: construction of the ring dike surrounding the polders to the west in alignment with Mont-Saint-Michel.

The land around Mont-Saint-Michel was therefore not reclaimed from the sea (figure 23) until successful channeling of the Couesnon in 1863 meant that polders could be built on its old estuary. Successive polder construction, implemented in parallel with the advance of the salt marshes, is marked by a network of dikes built thanks to the hard labor of the Mosselmann workers.
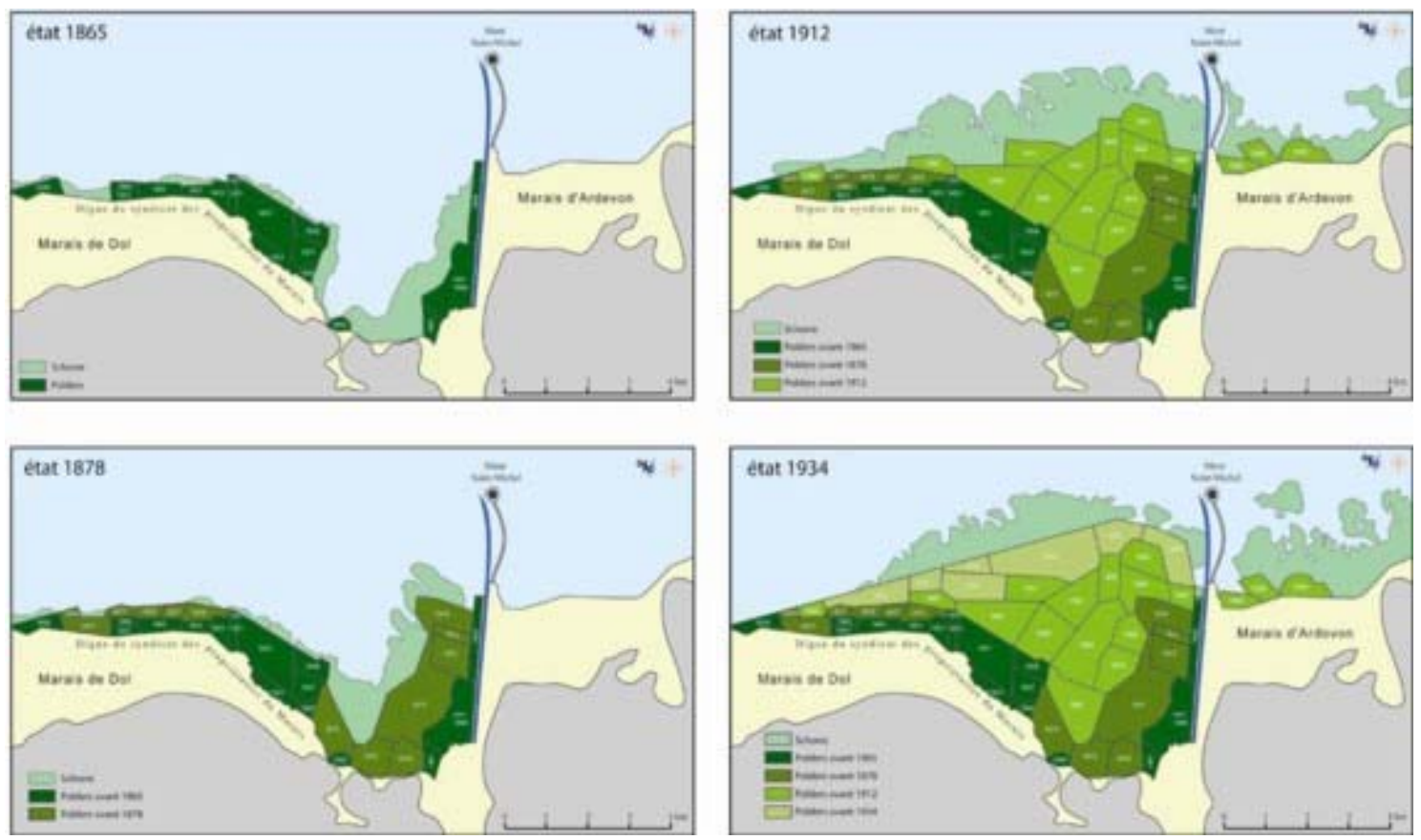

Figure 23. The main stages of land reclamation.

1969: Construction of the Caserne dam on the Couesnon,

this dam, fitted with sluice gates was built to prevent the tide from flooding the Couesnon river bed, reduced the volume of seawater which could enter this estuary and fostered clogging of its mouth on the tidal flats south of Mont-Saint-Michel. The riprap banks built since 1868 to stabilize the channel between the mouth of the Mosselmann 
channel and Mont-Saint-Michel were effectively covered by estuarine sediments from the Couesnon from 1972 onward (L'HOMER, 2002),

1970-1975: initial studies by the French Central Laboratory of Hydraulics (LCHF) in the field and on scaled-down models (MIGNIOT and VIGUIER, 2002) seeking solutions to reduce sedimentation around Mont-Saint-Michel and to stem the advance of the salt marshes. Sufficient hydraulic power to wash the sediments away could be restored by developing the Caserne dam, creating tidal reservoirs to the east, partially cutting the dike road and finally leveling the Roche Torin dike, which was the only work actually implemented;

1983: leveling of the Roche Torin dike to allow the common channel of the Sée and the Sélune to shift south and thus erode part of the salt marshes to the east of Mont-SaintMichel; a $500 \mathrm{~m}$ stretch of this dike was conserved at Roche Torin Point and a small area (10 ha) of these salt marshes was eroded by the shifting of the channel at the end of the present-day dike: however, the channel subsequently shifted northward and the eroded sediments were deposited on the eastern flank of the Great Bank, exacerbating the advance of the salt marshes nearest to Mont-Saint-Michel.

A large number of studies was conducted at the end of the 1990s in search of new solutions to restore the areas swept by the tides around Mont-Saint-Michel. New digital and physical models by SOGREAH (MIGNIOT and VIGUIER, 2002) resulted in new developments: the Caserne dam was extended and the sluice gates replaced by valves, the bed of the Couesnon was cleaned out, a flushing basin was created in Moidrey cove, the Couesnon channel was separated into two branches by means of a watershed equipped with deflector spurs, the dike road was cut and replaced by a footbridge at the approach to Mont-Saint-Michel, the car parks located at the foot of Mont-Saint-Michel were moved and a new car park was built on the mainland between Beauvoir and La Caserne.

2006: start of works directed by the Joint Initiative for Restoring the Marine Character of Mont-Saint-Michel; the first hydraulic works involved developments in Moidrey cove, dismantling the old dam at La Caserne and building a new one,

May 2009: the dam at La Caserne was put into operation; the first results from releasing the water show that the main Couesnon channel, aligned north-west in 2009, had shifted eastward, bypassing the foot of Mont-Saint-Michel (figure 24), which caused significant erosion in places (up to $2 \mathrm{~m}$ ). On either side of Mont-Saint-Michel, the upper mudflat at an elevation of at least $5 \mathrm{~m}$ IGN was reduced by about 30 ha; to the south-east of MontSaint-Michel, the salt marshes that had appeared in 2003 disappeared in 2011;

2010-2011: a car park was built on the mainland,

May 2012: the car park was opened and shuttle services to Mont-Saint-Michel itself were put into operation,

March 2012: construction work began (boreholes for the piers) on the footbridge, planned for completion in 2014. 

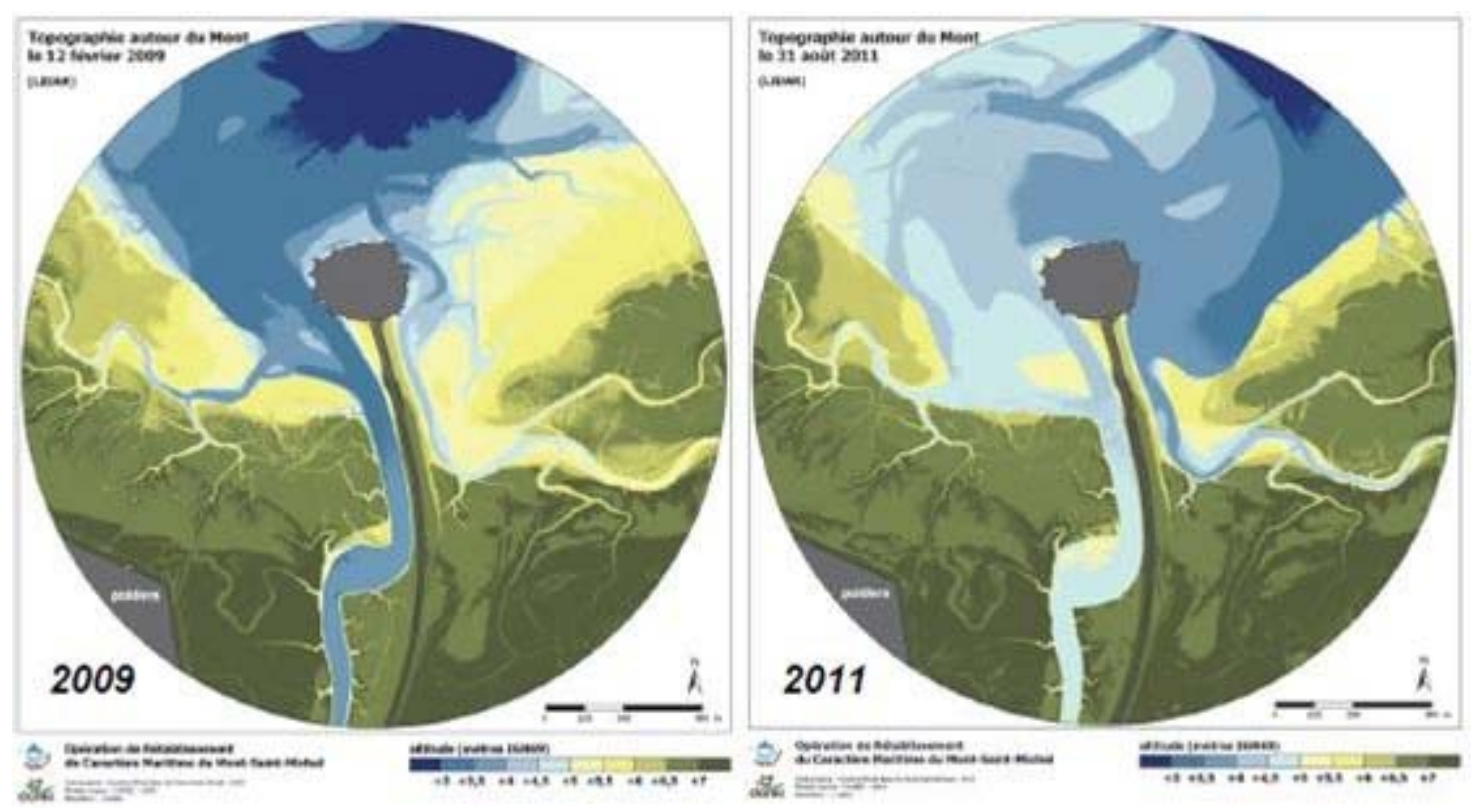

Figure 24. Changes in topography around Mont-Saint-Michel between 2009 and 2011, after R. DESGUEE, Mont-Saint-Michel bay Joint Initiative (2012).

\section{Conclusion}

The present-day configuration of Mont-Saint-Michel bay is the result of both, its natural evolution following the Holocene sedimentary infill linked to the last phase of the sea level rise, and developments which have marked the human occupation of this coastal fringe. The gradual clogging of the bay meant that large areas of marine marshland could be exploited. These marshlands were subsequently protected from marine incursions and shifting channels by dikes which demarcated the coastline. The exceptionally vast surface of the tidal flat favored the installation of fixed fisheries in the western part, and numerous salt works were established, mainly in the estuarine zone. The channeling of the Couesnon, land exploitation and the construction of dikes in the $19^{\text {th }}$ and $20^{\text {th }}$ centuries fundamentally changed the shoreline around Mont-SaintMichel. Shellfish farming, developed in the $20^{\text {th }}$ century, currently occupies most of the western lower tidal flat up to the network of estuarine channels. Present-day sedimentary dynamics are dominated by tidal processes, which in turn are superimposed by wave action which once again sets in motion the coastal barriers formed by the shell banks or the sand spits of the north-east coast.

The fact that sedimentation takes precedence over erosion and the steady progression of the salt marshes show that the natural accretion process in the bay is still in progress. Developments undertaken to re-establish the marine character of Mont-Saint-Michel aim to restore sufficient hydraulic power to surpass the cohesion of the sediments, in order to reduce sand deposits in the immediate vicinity of Mont-Saint-Michel itself. The 
redistribution of eroded sediments on either side of Mont-Saint-Michel will result in lateral extension of the salt marshes, but will have no significant effect on the sediment budget with respect to the entire Mont-Saint-Michel bay.

\section{Bibliographic references}

BILLARD C., BERNARD V., BOUFFIGNY A., QUEVILLON S. with the cooperation of CLAVEL B., BILLEAUD I., LAUTRIDOU J.-P., L'HOMER A., TESSIER B., (2006). Archéologie des pêcheries dans la partie nord-orientale de la Baie du MontSaint-Michel. Report from "Civilisations atlantiques et archéosciences", Rennes, 8 April 2006. Rennes, UMR 6566, CNRS, pp 61-63.

BILLARD C., BERNARD V., BOUFFIGNY A., CLAVEL B., COUTURIER Y., JAOUEN G., LEDIGOL Y., QUEVILLON S., ROPARS A. (2012). Techniques et modes d'exploitation des pêcheries sur le littoral normand (France) : un essai de bilan de 10 années de travaux archéologiques. In: Publication from the 2011 Homer Vannes symposium,

BILLEAUD I. (2006). Dynamique de construction d'un prisme sédimentaire littoral en régime mégatidal (la Baie du Mont Saint-Michel). Thesis, University of Caen, p. 239.

BIZIEN-JAGLIN C. (2008). Les sites et gisements archéologiques du marais de Dol. In Bonnot-Courtois C., Caline B., L'Homer A. Le Vot M. (dir) La baie du Mont- SaintMichel et l'estuaire de la Rance. Environnements sédimentaires, aménagements et évolution récente. Bull. Cent. Rech. Elf-Explor. Prod., Mémoire 26, Total Fina ElfCNRS-EPHE, pp 164-176.

BIZIEN-JAGLIN C. (2008). Le sous-sol du marais. Un livre d'histoire ...humaine, sédimentaire et environnementale. In "De Sainte Anne au Mont Saint-Michel. Marais et polders de la baie". Communauté de communes Baie du Mont Saint-Michel-Porte de Bretagne. Ille et Vilaine departmental archives (CG35), pp 15-20

BONNOT-COURTOIS C., MAZE J.P., LE VOT M., AUGRIS C., EHRHOLD A., SIMPLET L., BLANCHARD M. (2009). Morpho-sedimentary map of Mont-SaintMichel bay (Ille-et-Vilaine and Manche) scale 1:25,000, ed. Quae - Ifremer

BONNOT-COURTOIS C., BASSOULLET P., TESSIER B., CAYOCCA F., LE HIR P., BALTZER A. (2008). Remaniements sédimentaires superficiels sur l'estran occidental de la baie du Mont Saint-Michel. European Journal of Environmental and Civil Engineering, 978-2-7462-1971-7, Vol. 12, $\mathrm{n}^{\circ} 1-2, \quad$ pp 51-65. https://doi.org/10.1080/19648189.2008.9692995

BONNOT-COURTOIS C., CALINE B., L'HOMER A., LE VOT M. (ed.) (2002). La baie du Mont-Saint-Michel et l'estuaire de la Rance. Environnements sédimentaires, aménagements et évolution récente. [The bay of Mont-Saint-Michel and the Rance estuary. Recent development and evolution of depositional environments]. Bull. Cent. Rech. Elf-Explor. Prod., Mémoire 26, Total Fina Elf-CNRS-EPHE, pp 164-176. 
Intertidal sedimentary dynamics in Mont-Saint-Michel bay, a study of its natural evolution and man-made modifications: $n 02.33$

BONNOT-COURTOIS C., LEVASSEUR J.-E. (2000). Etudes en Environnement. Volume 5. Contribution à la connaissance de la dynamique des herbus. Final Report of the Joint Initiative for Restoring the Marine Character of Mont-Saint-Michel. Mission Mont-Saint-Michel, Manche Department Infrastructure Directorate (DDE). Univ. Rennes 1, CRI 8586 PRODIG CNRS. 196 p.

BONNOT-COURTOIS C., LEVASSEUR J.E. (2012). Organisation générale de la végétation littorale des estrans vaseux. In Manuel d'étude et de gestion des oiseaux et de leurs habitats en zone côtière. Chap. 1, Ecosystèmes estuariens et littoraux. pp 23-60.

DESGUEE R. (2012). Technical notes. Suivi de l'efficacité du Barrage. Syndicat Mixte Baie du Mont Saint Michel. La Baie. n² 29, pp 6-7.

EHRHOLD A. (1999). Dynamique de comblement d'un bassin sédimentaire soumis à un régime mégatidal : exemple de la baie du Mont-Saint-Michel. Thesis, University of Caen, 294 p. + annexes.

JORET E. (2008). Grèves vertes et grèves blanches. in "De Sainte Anne au Mont SaintMichel. Marais et polders de la baie". Communauté de communes Baie du Mont SaintMichel-Porte de Bretagne. Ille et Vilaine departmental archives (CG35), pp 27-39.

LARSONNEUR C. \& coll. (1989). La baie du Mont-Saint-Michel : un modèle de sédimentation en zone tempérée. Bull. Inst. Geol. Bassin Aquitaine, 46, pp 1-75.

LEFEUVRE J.-C. (ed.) \& coll. (1996). Effects of environmental change on European salt-marshes. Final report vol 2, Laboratoire d'Evolution des Systèmes Naturels et Modifiés. Univ. Rennes 1, MNHN, 251 p.

LEFEUVRE J.-C., MOUTON J.-P., MAUXION A. (2009). L'histoire de la baie du Mont Saint-Michel et de son abbaye. Editions Ouest-France. 287 p.

L'HOMER A., COURBOULEIX S., CHANTRAINE J., DEROIN J.P. (1999) with the cooperation of BONNOT-COURTOIS C., CALINE B., EHRHOLD A., LAUTRIDOU J.-P., MORZADEC-KERFOURN M.T., (1999). Geological map of France (1:50,000), Mont-Saint-Michel sheet, (208), Orléans, BRGM. Explanatory note. p. 183

L'HOMER A. (1995). Les vestiges de la pêcherie en bois de Saint-Jean-le-Thomas datent de l'âge du Bronze. In "Baie du Mont-Saint-Michel et Marais de Dol", L. Langouet \& M.-T. Morzadec-Kerfourn (dir.), Saint-Malo, Centre régional d'archéologie d'Alet. pp 119-124.

L'HOMER A. (2002). Impact sédimentologique des aménagements sur l'estuaire du Couesnon. In Bonnot-Courtois C., Caline B., L'Homer A. Le Vot M. (dir) La baie du Mont- Saint-Michel et l'estuaire de la Rance. Environnements sédimentaires, aménagements et évolution récente. Bull. Cent. Rech. Elf-Explor. Prod., Mémoire 26, Total Fina Elf-CNRS-EPHE, pp 153-163.

L'HOMER A., PIQUOIS C. (2002). Mont Saint-Michel bay Les anciennes salines. Siloë ed. 175 p.

L'HOMER A., BONNOT-COURTOIS C., CALINE B. (2002). Le prisme sédimentaire des dépôts du marais de Dol : essai de reconstitution de la mise en place des dépôts. In 
Bonnot-Courtois C., Caline B., L'homer A., Le Vot M. (dir), La baie du Mont- SaintMichel et l'estuaire de la Rance. Environnements sédimentaires, aménagements et évolution récente. Bull. Cent. Rech. Elf-Explor. Prod., Mémoire 26, Total Fina ElfCNRS-EPHE, pp 177-196

L'HOMER A. (2008). Passé géologique et naissance de la baie. In "De Sainte Anne au Mont Saint-Michel. Marais et polders de la baie". Communauté de communes Baie du Mont Saint-Michel-Porte de Bretagne. Ille et Vilaine departmental archives (CG35), pp 11-14.

MIGNIOT C. (1998). Rétablissement du caractère maritime du Mont-Saint-Michel. Synthèse des connaissances hydro-sédimentaires de la baie. Mission Mont-SaintMichel, Manche Department Infrastucture Directorate (DDE), p. 111

MORZADEC-KERFOURN M.-T. (2002). La sédimentation holocène dans la partie occidentale de la baie du Mont Saint-Michel: l'évolution du marais de Dol de Bretagne. In Bonnot-Courtois C., Caline B., L'Homer A. Le Vot M. (dir) La baie du Mont- Saint-Michel et l'estuaire de la Rance. Environnements sédimentaires, aménagements et évolution récente. Bull. Cent. Rech. Elf-Explor. Prod., Mémoire 26, Total Fina Elf-CNRS-EPHE, pp 153-163.

NIKODIC J. (1981). Dynamique sédimentaire dans la partie occidentale de la baie du Mont-Saint-Michel. Thesis 3rd cycle, University of Nantes, p. 180

SACHET C. (2008). Digues et contre-digues. in "De Sainte Anne au Mont SaintMichel. Marais et polders de la baie". Communauté de communes Baie du Mont SaintMichel-Porte de Bretagne. Ille et Vilaine departmental archives (CG35), pp 4160.

SORNIN J.-M. (1981). Processus sédimentaires et biodéposition liés à différents modes de conchyliculture. Thesis 3rd cycle, University of Nantes, p. 185

TESSIER B., BILLEAUD I., LESUEUR P. (2006) - The Bay of Mont-Saint-Michel northeaster littoral : an illustrative case of coastal sedimentary body evolution and stratigraphic organization in a transgressive/highstand context. Bull. Soc. Geol. Fr., t. 177, $\mathrm{n}^{\circ} 2$, pp 71-78. https://doi.org/10.2113/gssgfbull.177.2.71

TESSIER B., BILlEAUD I., BONNOT-COURTOIS C., CALINE B. (2007). Mont Saint-Michel bay. Facies, sequence, evolution 11th French Sedimentology Congress, Caen 2007, Excursion booklet, Publ. ASF, n 58, 48 p.

WEILL P., TESSIER B., MOUAZÉ D., BONNOT-COURTOIS C., NORGEOT C. (2010). Shelly cheniers on a macrotidal flat (Mont-Saint-Michel bay, France) - Internal architecture revealed by ground-penetrating radar. Journal of Sedimentary Geology, Vol. 17 December 2010. https://doi.org/10.1016/j.sedgeo.2010.12.002

WEILL P., (2010). Formation et évolution de cheniers en contexte macrotidal. Approches expérimentales et in situ. Thesis University of Caen, p $230+$ Appendices. 